\title{
A comparison of recent and fossil large, high-spired gastropods and their environments: the Nopparat Thara tidal flat in Krabi, South Thailand, versus the Swiss Kimmeridgian carbonate platform
}

\author{
Richard Waite $\cdot$ André Strasser
}

Received: 28 January 2010 / Accepted: 23 September 2010 / Published online: 19 October 2010

(C) Springer-Verlag 2010

\begin{abstract}
High-spired nerineoid gastropods are abundant in the tropical Kimmeridgian carbonate deposits of the Swiss Jura Mountains. Understanding the mode of life of this extinct group of gastropods is crucial for palaeoenvironmental reconstructions. The knowledge on their ecology is, however, limited by the near absence of comparable large high-spired gastropods in Recent carbonate systems. Large high-spired turritellid gastropods are, however, abundant in siliciclastic-dominated environments in the tropical Indian Ocean. In order to compare the Recent and fossil environments of these two morphologically similar groups, a Recent tidal flat, where abundant turritellids occur, was studied in the National Park of Nopparat Thara in the district of Krabi, South Thailand. Ninety specimens of Turritella duplicata were measured and mapped, revealing zonations in population distribution, both parallel and perpendicular to the beach line. Attention was also paid to other faunal elements and sedimentary features. The thusgained information on the depositional environment was then compared to a section of shallow-water carbonate deposits from the Kimmeridgian of the Swiss Jura Mountains. These are characterised by the occurrence of tidal laminites, dinosaur tracks, beach deposits and nerineoid gastropods. Especially for one succession, the faunal composition and sedimentary structures in the fossil record show intriguing similarities to those found today on the Nopparat Thara tidal flat, indicating that it formed in a comparable setting. It is therefore suggested that for some Kimmeridgian carbonate deposits, the Nopparat Thara tidal
\end{abstract}

R. Waite $(\bowtie) \cdot$ A. Strasser

Department of Geosciences, University of Fribourg,

Ch. du Musée 6, 1700 Fribourg, Switzerland

e-mail: richard.waite@unifr.ch flat, although dominantly siliciclastic, represents an environmental analogue.

Keywords Turritellidae $\cdot$ Nerineoidea $\cdot$ Jurassic .

Palaeoecology $\cdot$ Switzerland $\cdot$ Nopparat Thara tidal flat

\section{Introduction}

Nerineoid-bearing deposits in the Kimmeridgian (Late Jurassic) of the Swiss Jura Mountains have been recognised and described by several authors (e.g. Frei 1925; Thalmann 1966; Dauwalder and Remane 1979). Nerineoids are believed to be important palaeoecological indicators and the significance of their occurrence in mass accumulations has recently been re-evaluated (Waite et al. 2008). The mass accumulations are thought to represent semi-sessile communities, which colonized stable surfaces in agitated environments where sufficient food was available. The enormous populations in these mass accumulations support the conclusion that nerineoids were most likely suspension feeders. A possible source of food to sustain such populations was input of particulate organic material either by runoff from emerged parts of the platform or by coastal erosion during transgression (Hallock and Schlager 1986; Nara 2002; Waite et al. 2008).

The nerineoids were a diverse superfamily of Mesozoic gastropods (Sohl 1987) with over 90 published genera (Barker 1990). The superfamily Nerineoidea (Zittel 1873) ranges from the Hettangian to the Maastrichtian (Pchelintsev 1965; Barker 1990, 1994), although the earliest forms have been reported from the Triassic of Turkey and Germany (Peter W. Skelton, pers. comm. 2008; Karl Stransky, pers. comm. 2008). They were common in tropical and subtropical environments around the world (Wieczorek 1992). 
Their northern and southern limits of distribution coincide with the latitudinal limits of the tropical reef belts during the Late Jurassic (Ziegler 1964). Nerineoids were a group of mainly high-spired gastropods, which preferentially inhabited carbonate platform environments (Sohl 1987). They are described from practically all limestone facies: from high-energy oolitic and coral limestones to the lowenergy peloidal and micritic facies. Nerineoids are commonly associated with corals and rudists and monospecific occurrences are rare. Usually several different species occur together (Wieczorek 1979). Nerineoids have no extant descendants; therefore several authors have compared them to the family Turritellidae (Lovén 1847) on behalf of morphological similarities, gregarious behaviour, and possible common ancestors (Deecke 1916; Pchelintsev 1965; Signor and Kat 1984; Barker 1990).

Turritellids (family Turritellidae) arose in the Late Mesozoic and have continued to the Recent, showing a worldwide distribution (Allmon 1988; Allmon and Cohen 2008). Turritellid mass occurrences were common in both siliciclastic and carbonate environments during the Cretaceous and Paleogene (Allmon and Knight 1993; Allmon 2007; Allmon and Cohen 2008; Allmon and Harris 2008). Since the Miocene, turritellid mass accumulations apparently only occur in siliciclastic environments (Allmon and Knight 1993; Allmon 2007). Recent turritellids are most abundant in cool water commonly associated with areas of upwelling and rare in tropical carbonate environments (Allmon 1988; Allmon and Knight 1993). The possibility of an ecological change of the group has been inferred due to the absence of recent species in carbonate environments compared to the high frequencies in parts of the Tertiary and Cretaceous (Allmon 2007). Although mass accumulations are reported from several localities around the world in both fossil and Recent environments, they also commonly occur in low and variable abundances. Turritellids may have changed from mainly thermophilic to mainly nonthermophilic during the Cenozoic (Allmon 1992). The turritellids are a diverse group with over 2000 recent and fossil species and subspecies (Allmon 1996), of which about 500 are extant (Allmon 1988).

Turritellids today occur in a number of different environments. They range from intertidal to $1500 \mathrm{~m}$ water depth although they are most common between 10 and $100 \mathrm{~m}$. They inhabit waters from the Arctic (Parker et al. 1865) to the tropics (Allmon 1988) with temperatures ranging from 2 to $30^{\circ} \mathrm{C}$, although the group as such seems to prefer moderate temperatures $\left(<20^{\circ} \mathrm{C}\right)$. They are primarily animals of normal marine salinities, but several species live in salinities well below 35\%o. They apparently do not tolerate hypersaline conditions. They are found on many different types of substrates ranging from silt to gravel and even rock surfaces in a number of hydrodynamic regimes including the high-energy surf zone and reef environments (Bax et al. 2003). They may have an epifaunal or infaunal mode of life and are commonly ciliary suspension feeders. However, some are mucus string feeders, some may be exclusive or facultative deposit feeders and others apparently change the dominant trophic mode according to seasonal phytoplankton availability (Allmon 1988; Bax et al. 2003). Reproduction is seasonal for all known species. Some appear to spawn twice a year and others possibly more frequently. High densities of similar-sized adults at times of reproduction may indicate synchronous mass spawning (Allmon 1988 and references therein). Many turritellids remain stationary for long periods of time and they are found in a variety of life positions (Allmon 1988). They can, however, also be highly active and certain species are believed to "migrate" hundreds of metres or kilometres during days or weeks, activity apparently being greatest at night (Allmon 1988; Allmon et al. 1992). Turritellids are prayed on by fish, stingrays, naticid and muricid gastropods, bulloid opisthobranchs, decapod crabs, sea stars and octopus (Dudley and Vermeij 1978; Allmon 1988; Allmon et al. 1992; Bax et al. 2003). Estimates of life spans for different species of turritellids range between $2-3$ and $10-15$ years based on isotope profiles and growth line counts (Allmon 1988; Allmon et al. 1992; 1994; Bax et al. 2003). The limited data available for growth speed, size and maturity relations suggest that no conclusions can be drawn from one species to another. Some specimens grow faster and lay down greater amounts of shell when younger and smaller. The reduction in shell growth may reflect an ontogenic decline as more investment is put into reproduction. For temperate species, growth is seasonal, with the most rapid growth occurring during the warmest months, particularly in the first year of life (Bax et al. 2003). Little is known about the mode of life of individual species of turritellids (Allmon 1994), and for tropical species very little literature is available. In view of the heterogeneity of the turritellids, and to a lesser extent also the nerineoids, it becomes clear that it is not practical to simply compare the two groups. Nevertheless, turritellids in the Cretaceous inhabited similar shallow, high- and lowenergy, subtidal to intertidal platform environments as nerineoids (Allmon and Cohen 2008) and sometimes occurred in the same or in adjacent environments (Zeuschner 1849; Allison 1955).

Thermophilic species of turritellids have continued to the Recent and large, thick-shelled species still inhabit modern tropical platform environments. To observe such specimens in the their natural habitat, a field study was conducted during an 8-day period from the 10th to 17th of February 2008, on the tidal flat of the Nopparat Thara beach, part of the National Park of Nopparat Thara in the district of Krabi, South Thailand. This locality was chosen because it is one of the very few tropical occurrences of turritellids 
for which any information could be found. The information came mainly from reports of, and personal communication with several experienced shell collectors who characterised the Nopparat Thara area as an easily accessible and excellent locality for finding large intact shells. A characterisation of the environment and summary of the results of this field study are presented in the first part of this paper. Based on these insights, a short section of tidal flat deposits, bearing abundant nerineoids from the Kimmeridgian of the Swiss Jura Mountains is discussed and interpreted in the second part. In absence of any literature on the behaviour of nerineoids or comparisons between nerineoids and live gastropods, this work presents several behavioural and anatomical details of turritellids, which may tentatively be counted as reference values for nerineoids. Although mass accumulations (estimated densities ranging from 7,00027,000 specimens/m³ ${ }^{3}$ Dauwalder and Remane 1979; Waite et al. 2008) are the predominant nerineoid-bearing deposits on the platform, there are also beds, which contain fewer nerineoids with a conspicuous accompanying fauna. While the mass accumulations have repeatedly been the focus of palaeoecological research (e.g. Vogel 1968; Dauwalder and Remane 1979; Wieczorek 1979; Sirna 1995) the beds containing moderate numbers of nerineoids have so far not been placed in the context of a specific environment.

\section{Materials and methods}

The tidal flat and beach of Nopparat Thara was documented and analysed for coast morphology and faunal abundance and diversity with a special focus on the population of turritellid gastropods. A total of 77 live and 13 well-preserved dead specimens were collected from the beach and tidal flat. Specimens were measured in length and basal width and documented and catalogued with regard to their location and position on the flat or beach, their state of preservation and any unusual or interesting features. After examination, the live turritellids were returned to the field. Four excavations over an area of $9 \mathrm{~m}^{2}$ to a depth of $5 \mathrm{~cm}$ were conducted to document frequencies and variations of shallow infauna across the flat. Sediment cores $6 \mathrm{~cm}$ in depth were extracted, documented and sampled. Samples were then taken back to the lab, dried and stabilised with artificial resin. Three samples from the cores were used to make thin sections for sediment description, analysis and comparison. One sample of surface sediment from the flat was dried for several days in an oven at $80^{\circ} \mathrm{C}$. Ten grams of sediment powder was precisely weighed and then reacted with $10 \%$ hydrochloric acid to remove the carbonate fraction. The remaining sediment was rinsed in filter paper with distilled water, dried again for several days in the oven and weighed again to calculate weight percent carbonate. The flat was monitored and documented both when accessible during low tide and during high tide by means of snorkelling. Water parameters (salinity, alkalinity, specific gravity, $\mathrm{pH}, \mathrm{Ca}$ and $\mathrm{Mg}$ contents) were measured with a SALIFERT test kit. Temperature measurements were made with a dive chronometer and visibility was estimated during snorkelling. Five well-preserved shell specimens were brought back to the lab. All shells were treated with $20 \% \mathrm{H}_{2} \mathrm{O}_{2}$ to remove organic remains. Opercula are stored in ethanol. Shells were measured precisely, weighed empty and filled with water to estimate weight and volume of the living animal. Speed measurements were made for three specimens, one moving along the sediment and two during the process of burrowing.

For comparison with the fossil record, a short section, $3 \mathrm{~m}$ in height, of early Late Kimmeridgian shallow-water limestone and marls deposits was measured, sampled and described from the locality Sur Combe Ronde near Courtedoux in the north-western Swiss Jura Mountains. Due to excellent outcrop conditions, some surfaces could be studied in addition to the vertical section. In total, 39 standard sedimentological rock samples were taken every $10 \mathrm{~cm}$, or below and above bedding planes where facies changed. At least one thin-section and one polished section were obtained from each sample to document, analyse and compare micro- and macro-facies and composition. Marls were washed, sieved and picked under a binocular microscope.

\section{Geographical and geological setting of the Nopparat Thara beach}

The Nopparat Thara beach is situated on the Phang Nga Bay coast and forms the extension of the Ao Nang beach. It lies west of Ao Nang in the district of Krabi, South Thailand (Fig. 1). The morphology of the coastline in the region is extremely variable. In semi-protected east-facing bays like Railay East, the coast is formed by a tidal flat with thick mud deposits in between irregular karstified rocks that grade into a mangrove swamp. However, anthropogenic modification of the coast makes it difficult to be sure of the original vegetation and structure of the flats. Further along the coast, sand flats and mud flats alternate with steep cliffs, the mud flats predominantly facing east and the sand flats west.

The region's climate is dominated by the reversing monsoon, which is responsible for a rainy season and southwesterly winds from April to October and a dry season with north-easterly winds from November until March. Rainfall averages around $300 \mathrm{~mm} / \mathrm{month}$ in the wet season and $50 \mathrm{~mm} / \mathrm{month}$ in the dry season. Sea surface temperatures range from $27-31^{\circ} \mathrm{C}$ and salinities are generally in the range between 32 and 33\%o (Tudhope and Scoffin 1994). 


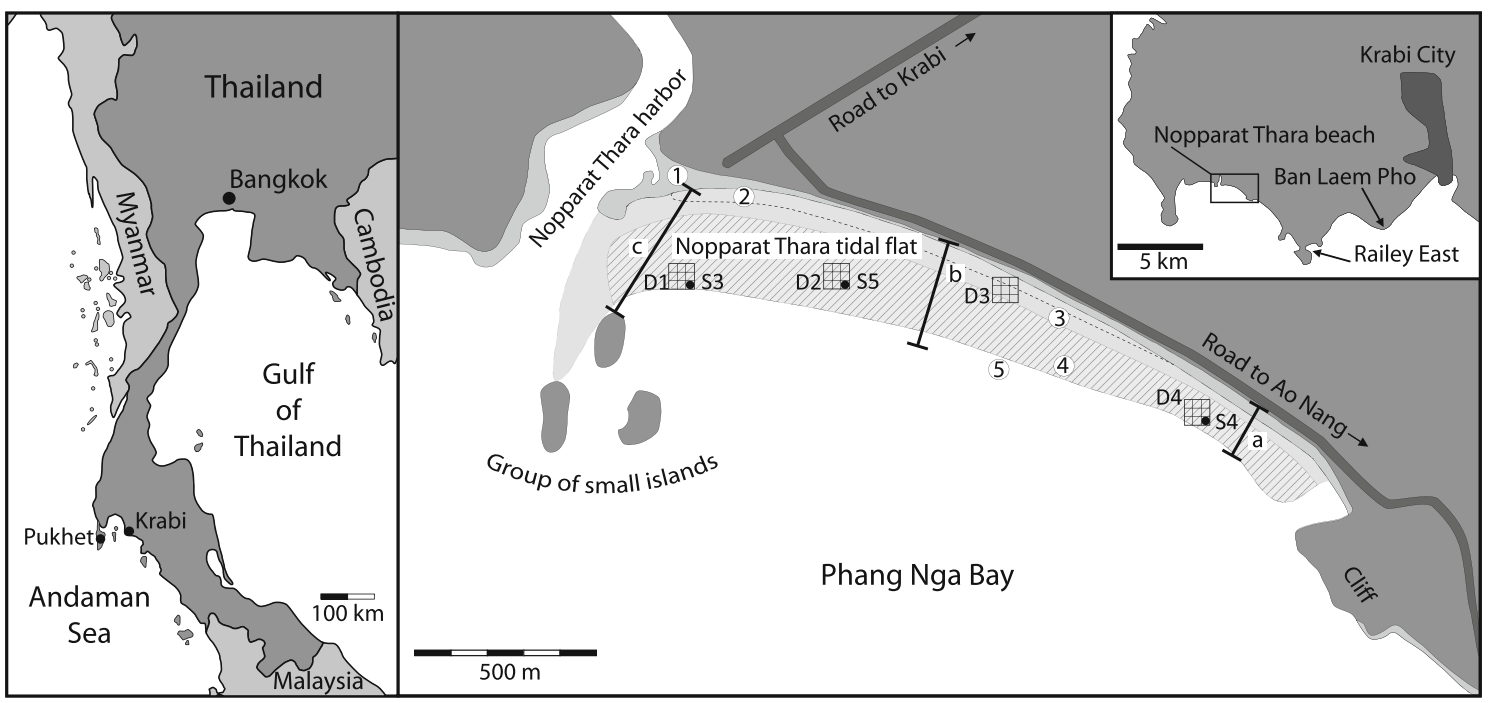

Fig. 1 Map of the study area depicting the extent of the Nopparat Thara tidal flat, its position on the Andaman Sea coast and the location of the obtained sediment samples. 1 Beach, 2 Near shore or ocypode zone, 3 Intermediate zone, 4 Turritellid zone, 5 Firmground zone.

The Nopparat Thara beach is separated from the Ao Nang beach by a relatively steep stretch of coastline, which forms a small cliff and is defined here as the eastern termination of Nopparat Thara (Fig. 1). The western termination of the beach is an estuary, which forms a busy harbour for long-tail and tourist boats. Nopparat Thara Beach is known by collectors for its rich and diverse shell fauna. Tides are diurnal and tidal range varies strongly. During the study, tides varied from about $3.20 \mathrm{~m}$ at spring tide to about $1 \mathrm{~m}$ at neap tide. The dynamics of the beach change due to variations in tidal range. This is reflected in the distribution of the shell beds on the beach. During spring tide, a continuous accumulation is formed at the beach foot, whereas during neap tide, large lenses are formed on the beach. Winds during the surveying period were weak, but consistent from the southeast. The appearance of the tidal flat changes from east to west (Fig. 1). The extreme east is characterised by a relatively narrow beach approximately $15 \mathrm{~m}$ wide. Just below the beachfront patches of rock and dead coral occur, which are inhabited by algae of the genus Padina. The dip of the tidal flat is steeper in the east, so during low tide less of the surface is exposed. The beach gradually becomes narrower and reaches its narrowest extent in the central part where at high tide there is almost no beach at all and the water comes up to an artificial wall, which runs along the beach and protects the road during strong surf. The beach becomes broader again in a westerly direction and stretches out furthest where a sand-spit is formed along the river mouth in the extreme west due to long-shore currents and sediment transport. The tidal flat is less steep in the west, leading to a larger expanse of the flat being exposed at low tide. In front and slightly to the east of the river-mouth are $a-c$ refer to the positions of the transects described in Fig. 2. D1-D4 refer to the positions of the excavations on the tidal flat. $S 3, S 4, S 5$ refer to the locations of the surface samples obtained from the tidal flat

three small islands. The westernmost of these can be reached by walking at low spring tide. The rocks around the island are colonised by corals and sponges forming small patch reefs. There is a diverse fauna consisting of numerous fish and invertebrates. Faunal diversity decreases towards the east. The sediment is dominantly composed of quartz grains with a minor fraction of biogenic carbonate clasts. No clays are deposited in the intertidal regime. The sediment on the tidal flat is characterised by an oxidized superficial layer $2-3 \mathrm{~cm}$ thick of grey sand overlying a darker, organic-rich, almost black layer below. The tidal flat shows a strong zonation. The near-shore zone is characterised by the activity of innumerable ocypode crabs, which, during low tide, re-open and maintain their burrows. The width of this zone varies from the west where it is $30 \mathrm{~m}$ broad to the central part where it is only approximately $10-15 \mathrm{~m}$ wide and then narrows and finally disappears towards the east (Fig. 1). In this zone, small turritellids are also rather common. Beyond is an intermediate zone where many infaunal bivalves, polychaetes, starfish, crabs and naticid gastropods occur. In the west, echinoid sand-dollars are also common constituents but they rapidly become less frequent towards the east and are absent in the central and eastern parts of the flat. Starfish are still commonly encountered in the central part of the flat but their frequencies also gradually decline towards the east. Hermit crabs and small nassariid gastropods are generally present in the ocypode and intermediate zones. Besides the aforementioned faunal elements, beyond the intermediate zone large specimens of turritellids are common down to the low tide line and into the marginally subtidal facies and these define the turritellid zone. The band along the low neap tide line, comprising the marginal 

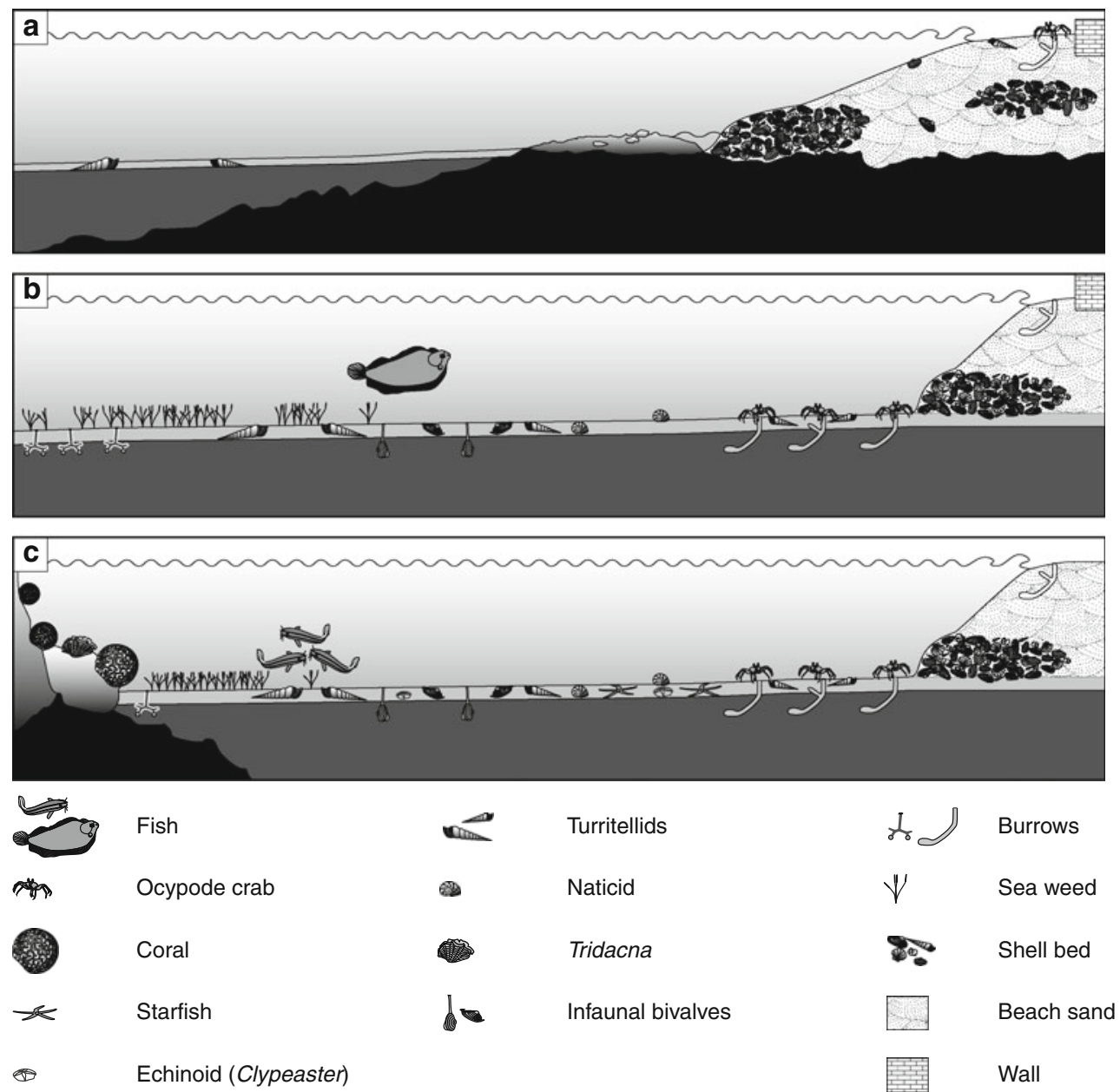

Fig. 2 Schematic transects from the beach to the low tide line. a Eastern part characterised by an almost monospecific fauna and rocky substrate. b Central part characterised by sea grass and by an

intertidal to marginal subtidal facies, is covered by patches of wispy, thin sea grass. Approximately $15 \mathrm{~m}$ beyond the low tide line lies a zone of firmground characterised by intensive burrowing by crustaceans. No turritellids were encountered in this zone. The changes in faunal diversity, both parallel and perpendicular to the beach, as well as the change in morphology of the tidal flat, are depicted in three schematic transects $a$ to $c$ from east to west through the different zones in Fig. 2.

During the study period, water temperature was generally around $28^{\circ} \mathrm{C}$. Visibility in the water was, depending on waves and tide, between $30 \mathrm{~cm}$ at its lowest and $4 \mathrm{~m}$ at its highest. Water chemistry showed normal marine conditions with a $\mathrm{pH}$ of 8.0 and salinity of $33 \%$.

The grain size distribution of three shallow core samples is presented in Fig. 3a. Grain size does not vary much parallel to the beach. In the east there is a higher fraction of smaller grains and grain sizes of siliciclastics vary between 0.05 and $0.35 \mathrm{~mm}$. Skeletal carbonate remains are larger intensely bioturbated firm-ground zone. $\mathbf{c}$ Western part of the flat characterised by diverse fauna and islands with small coral reefs

but are mainly found on the beach and are relatively rare on the flat. A thin-section micrograph of a core sample from the east of the tidal flat embedded in artificial resin is provided in Fig. 3b.

\section{Turritellids}

Turritellid gastropods are common on the Nopparat Thara tidal flat. Four different species of turritellids are reported from the area by numerous shell collectors: (1) Turritella attenuata (Reeve 1849); (2) Turritella vittulata (Adams and Reeve 1825); (3) Turritella duplicata (Linnæus 1758); (4) Turritella terebra (Linnæus 1758) (see also Carpenter and Niem 1998). The presence of two of these could be unequivocally confirmed. T. duplicata (Fig. 4) is common both as dead shells on the beach and as living specimens on the tidal flat, whereas T. terebra was only found dead on the beach. This implies either that the T. terebra live 


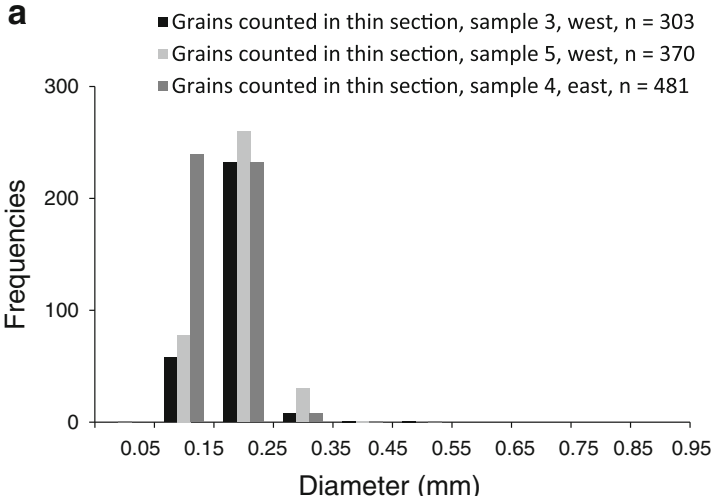

C

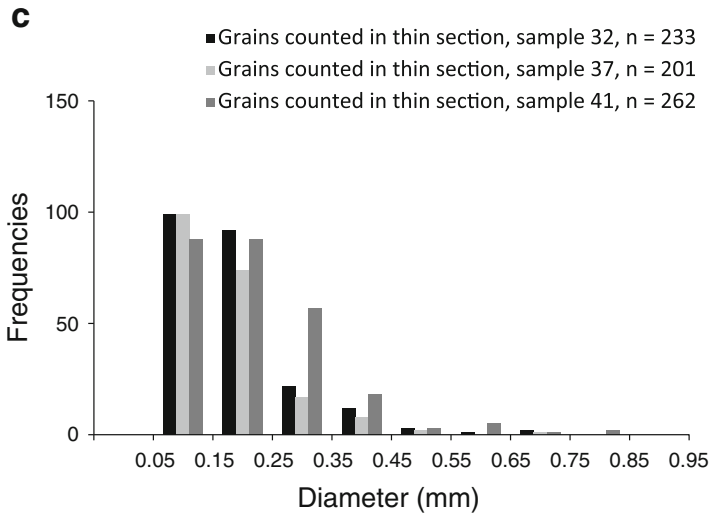

Fig. 3 Grain size distribution plots and sediment micrographs. a Frequencies versus grain diameter plots of three samples of surface sediments from the Nopparat Thara tidal flat. b Thin-section micrograph of sediment sample 4 embedded in artificial resin. For position

further out in an environment permanently covered by a few metres of water, or further to the east possibly in front of the cliff. Unfortunately, due to heavy boat traffic along the coast, the study area was limited to the intertidal and shallow subtidal zones. Little information was obtained from the deeper subtidal zone. The living $T$. duplicata apparently occur in two different zones on the flat. The first is the near-shore zone, which in the central part seems more or less congruent with the ocypode zone but extends somewhat beyond into the intermediate zone in the west. The near-shore population consists of relatively small specimens with maxima in length between 6 and $7 \mathrm{~cm}$ (Fig. 5). The second population is found further out on the flat in a zone starting about $80 \mathrm{~m}$ from the beach and ending just beyond the low-tide line in the west and $30 \mathrm{~m}$ from the beach up to the low-tide line in the east (Turritellid zone in Fig. 1). This second population shows two maxima in shell length, one between 9.5 and $10.5 \mathrm{~cm}$ and another between 13 and $14 \mathrm{~cm}$ (Fig. 5). Apparently, the larger specimens live further out on the flat. The largest live specimens were found in the sea-grass meadows, where even during low spring tide there are still a few centimetres of water cover.
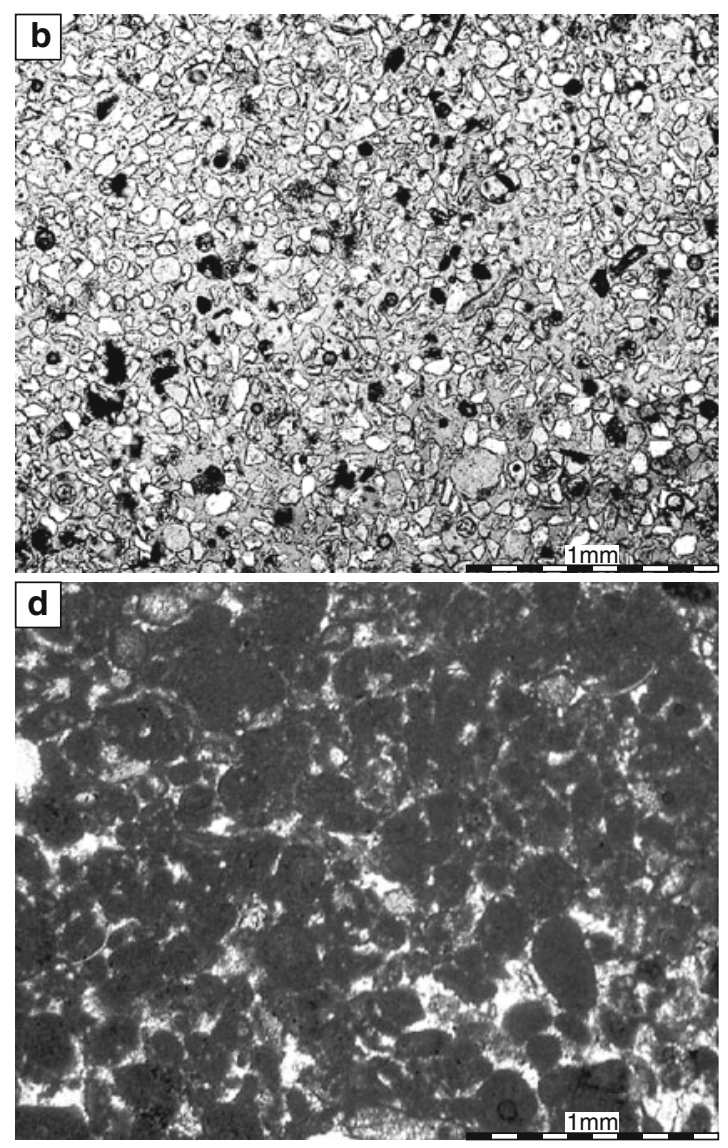

of samples see Fig. 1. c Frequencies versus grain diameter plots of three samples from the Pseudonerinea-dominated assemblage at Sur Combe Ronde. d Thin-section micrograph of rock sample 32. For position of samples see Fig. 9

The frequency and distribution of fauna in general varies along the flat from west to east (Fig. 2). In the west, $180 \mathrm{~m}$ from the beach foot and slightly to the east of the islands, a systematic excavation (D1 in Fig. 1) of the topmost $5 \mathrm{~cm}$ of sediment over an area of $9 \mathrm{~m}^{2}$ revealed: eight sand-dollar type echinoids (order: Clypeasterina), four starfish, one $T$. duplicata and one crab. In the central part of the beach, two digs of equal size and depth were conducted. The first (D2 in Fig. 1) was located in the Turritellid zone about $120 \mathrm{~m}$ from the beach and yielded two T. duplicata and one crab. The second (D3 in Fig. 1) was a few hundred metres further east and closer to the beach at approximately $40 \mathrm{~m}$. In this excavation, no macrofauna was found. Between these two sites eight naticid gastropods were encountered moving along just below the sediment surface. Some naticids and muricids are known to pray on turritellids (Dudley and Vermeij 1978; Arua 1989; Arua and Hogue 1989; Allmon et al. 1992; Hagadorn and Boyajian 1997). Evidence of gastropod predation on turritellids was found in several shells (e.g. Fig 6a). In the east, the ocypode crab burrows do not occur and no near-shore turritellids were observed. This may be due to the difference in the morphology of the tidal 


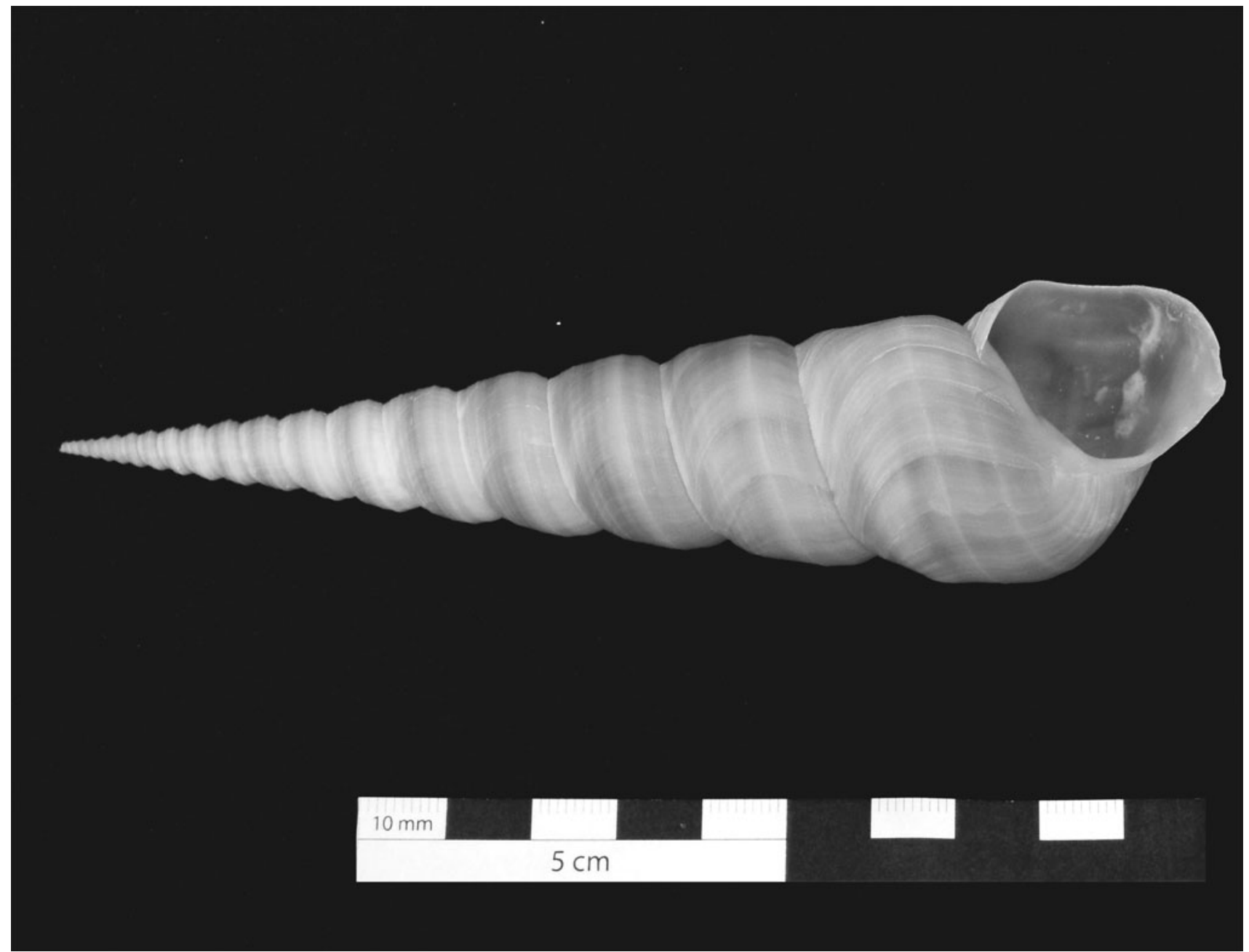

Fig. 4 T. duplicata (Linnæus 1758) ventral view. Specimen no. 87, Nopparat Thara

flat. As noted above, at some points the flat is rocky and during low tide ponds tend to be formed in the zone where further to the west the ocypode burrows occur. On account of its steeper inclination, in the east the tidal flat is narrower. Turritellids occur only in a narrow zone. Fifty metres from the beach a $9 \mathrm{~m}^{2}$ excavation (D4 in Fig. 1) of the uppermost $5 \mathrm{~cm}$ of sediment revealed one $T$. duplicata. No other macrofauna was recovered apart from small hermit crabs. The near-shore population is exceedingly exposed to currents during times of strong wave action. On one afternoon, over 30 rather small $(6-7 \mathrm{~cm}$ long) specimens of $T$. duplicata were thrown up onto the beach in the central part. Many of these remained immobile with the operculum loosely closed. A few, however, were highly active and were trying to make their way back into the water. While almost all of these specimens showed slight damage to the aperture, only a few were dramatically broken at apex or aperture or both. During the following low tide it was evident that many specimens in the near shore zone were changing their position.
Two specimens were found burying themselves. They were completely unearthed again and the time from the moment they began moving after having been placed on the substrate until they were completely buried was measured. Specimen no. 2 had a length of $13.5 \mathrm{~cm}$ and was $3.5 \mathrm{~cm}$ in diameter at the base. The apical whorls had been broken off. It took 32 min until it was completely buried with no water cover. Specimen no. 82 was $5.3 \mathrm{~cm}$ long and $1.8 \mathrm{~cm}$ in diameter at the base. It took $3 \mathrm{~min}$ and $50 \mathrm{~s}$ to bury itself and start feeding in a pond with $2 \mathrm{~cm}$ of water cover. It was evident that the surrounding water and the wave motion of the covering water facilitated the burying process. Specimen no. 88 was found moving along the flat about $4 \mathrm{~m}$ away from the beach. Its mode of propulsion was such that it extended the foot far out of the aperture and then dragged its shell after it, thus ploughing through the sediment. It was monitored and filmed for almost $5 \mathrm{~min}$ : its speed averaged approximately $6 \mathrm{~m}$ per hour and it achieved one "step" every $4-5 \mathrm{~s}$. During this time, it was dislodged and rolled around several times by incoming waves. This caused it to 
Fig. 5 Turritellid size distribution on the Nopparat Thara tidal flat $(n=90)$. Smaller individuals generally inhabit a zone near to the shore whereas larger individuals apparently prefer a habitat closer to the low tide line

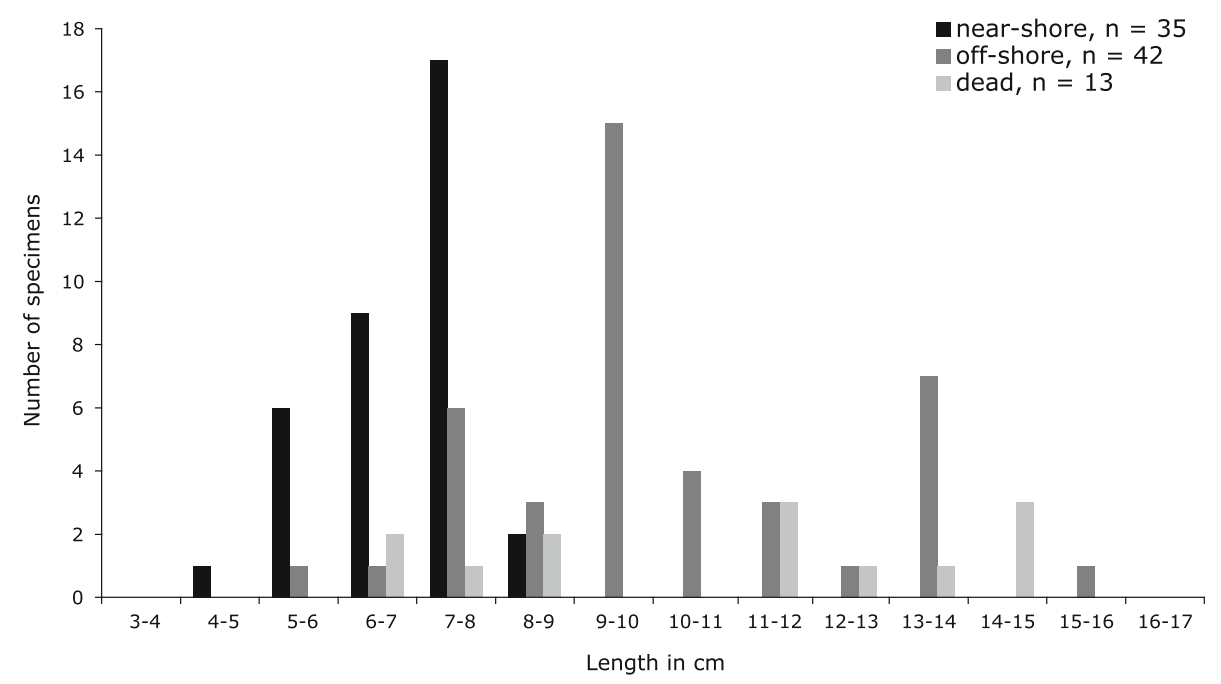

involuntarily change direction sometimes by up to $90^{\circ}$. Nevertheless, it kept on moving with the same speed seemingly unconcerned about direction. The priority of the study focused on the documentation of live turritellid specimens but some basic observations on preservation were also recorded. Shells on the flat were encountered in all states of preservation from practically pristine when recently dead and still containing the opercula (Fig. 6b, d), showing minor shell modification such as drilling by naticid or muricid gastropods (Fig. 6a) or commencing encrustation (Fig. 6c) to severely fragmented or encrusted (Fig. 6e, f). Encrustation of live specimens was rarely encountered and then only by algae. Large intact dead specimens on the tidal flat are commonly rapidly colonised by hermit crabs and subsequently strongly encrusted by barnacles and limpets (Fig. 6f) as the crabs remain on the sediment surface. In the beach rubble, complete shells were rarely encountered and the skeletal elements are commonly strongly fragmented. Thousands of small shells of turritellids, presumably mainly consisting of the broken-off apexes of large specimens were found on the proximal flat all inhabited by hermit crabs. Empty shells in good condition on the flat are rare. During the study, only two turritellid shells were found on the flat, which were in pristine condition and still contained the partially decomposed animal and the operculum.

Weight measurements were made of two well-preserved shell specimens in the lab using a precision scales. The shell of specimen no. 87 (Fig. 6b) weighed $54.26 \mathrm{~g}$ when dried and $79.83 \mathrm{~g}$ when filled with water to simulate the weight of the organic tissue of the soft parts. It was $14.4 \mathrm{~cm}$ in length and had 19 preserved whorls. It was about $1 \mathrm{~mm}$ wide at the apex, some of the juvenile shell having been broken off, and $3.4 \mathrm{~cm}$ in diameter at the base. The aperture was undamaged. Consequently, the internal volume was calculated to be approximately $25 \mathrm{~cm}^{3}$. The shell of specimen no. 89 (Fig. 6a) weighed $5.51 \mathrm{~g}$ when dry and $9.22 \mathrm{~g}$ when filled with water. It was $6.8 \mathrm{~cm}$ in length and had 16 preserved whorls. It was about $0.8 \mathrm{~mm}$ wide at the apex, some of the juvenile conch having been broken off, and $1.7 \mathrm{~cm}$ in diameter at the base. The aperture was slightly damaged. Its internal volume was computed as comprising approximately $3.75 \mathrm{~cm}^{3}$.

\section{Discussion of the Nopparat Thara tidal flat}

The frequency distribution of the measured population of turritellids is presented in Fig. 5. This population represents but a fraction of the true population on the flat because the individuals are generally buried in the sediment and therefore not easily found. It seems that many turritellids live semi-infaunally or infaunally for most of the time. The specimens on the flat were most often found living almost completely covered in the sediment with just a small area of uncovered shell and two sub-circular holes, corresponding to the excurrent and incurrent openings, visible at the surface (Fig. 7). However, other positions included simply lying completely exposed on the surface with the operculum loosely closing the aperture, apex sticking down in the sediment, or moving across the sediment. Furthermore, the near-shore population was less often encountered either during low or high tide than

Fig. 6 Examples of the preservation state of dead specimens of T. duplicata from the Nopparat Thara tidal flat. a Successful drilling predation by naticid or muricid gastropod. b, d Pristine shells found still containing opercula. $\mathbf{c}$ Encrustation by barnacles but not colonised by hermit crab. e Severely damaged at both apex and aperture. f Strongly encrusted by barnacles and limpets as well as serving as substrate for other gastropods and inhabited by a large hermit crab (scale in centimetres) 


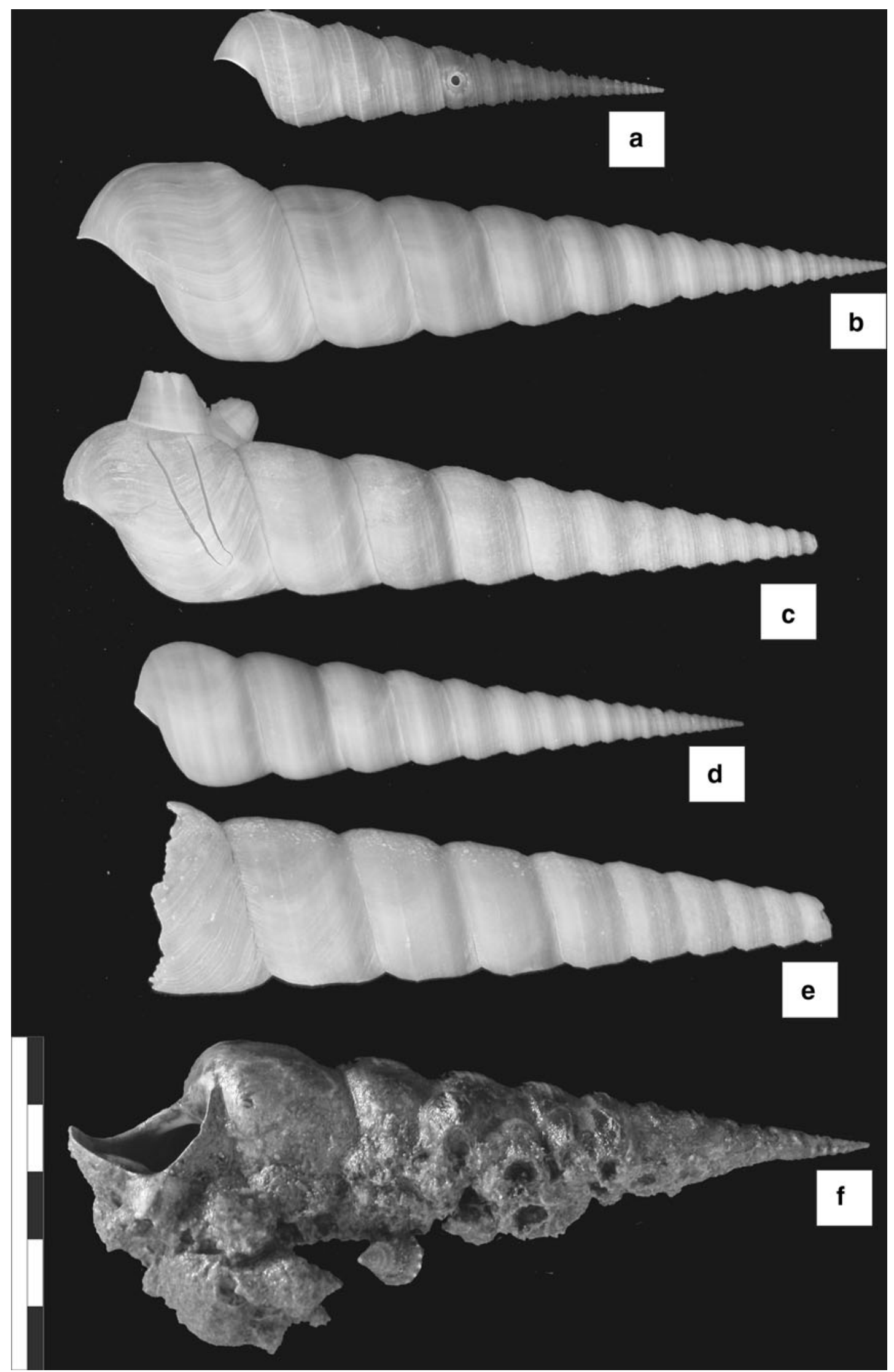




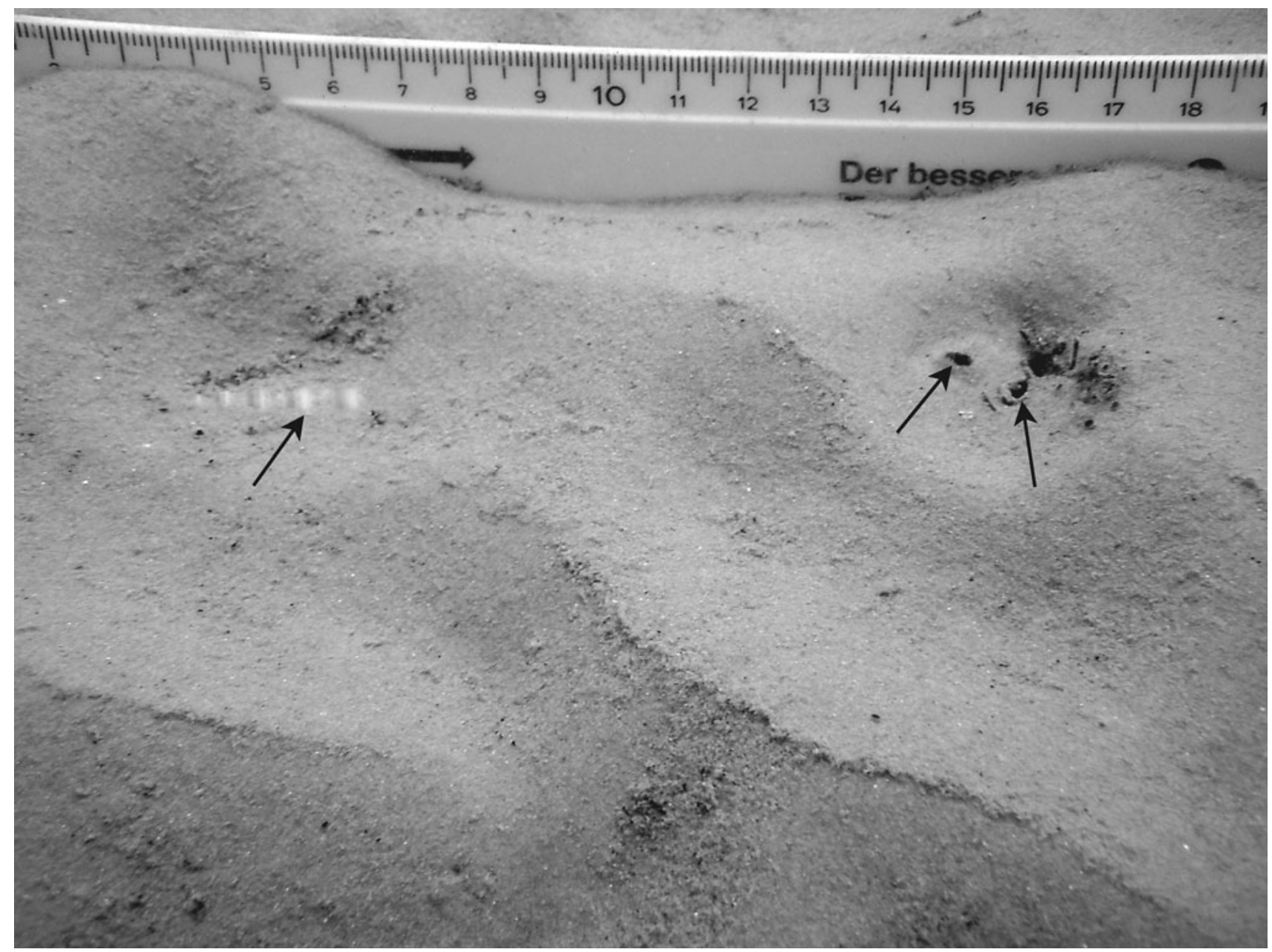

Fig. 7 T. duplicata in feeding position. Picture was taken in about 2-m water depth. Note the small section of exposed shell at the apical end (arrow on the left) and the two sub-circular holes for the inhalant and exhalent currents (arrows on the right)

the larger specimens living further out. It is therefore possible, that to a certain extent, these smaller specimens live completely buried in the sediment, and/or that they are nocturnal and actively filter feed only during the night. Most of the data on the near-shore population was gathered during 1 day of strong surf when many small specimens were unearthed. It is important to emphasize that this population is but a snapshot in time and that the abundance and distribution of the turritellids is likely to change depending on the season. For example, Turritella gonostoma reproduce during winter in shallow surface water and disappear again in spring (Allmon et al. 1992; Cadée et al. 1997). The fact that no specimens smaller than $4 \mathrm{~cm}$ were encountered on the flat may indicate that the population represents a community of mature adults. A study on gonad development on the turritellide species Maoricolpus roseus in Australia revealed that maturity for both males and females is reached at sizes between 3 and $4 \mathrm{~cm}$ (Bax et al. 2003). For the Nopparat Thara tidal flat this implies that: (1) young specimens live infaunally and deeper in the sediment, or (2) that the juvenile specimens live in a deeper marine environment, or (3) that reproduction for this species is infrequent. Regarding the first point, specimens of the relatively small species Turritella trisulcata living $10 \mathrm{~cm}$ deep in the sediment have been observed in the Red Sea (Allmon 1988; pers. obs. 2009).

The conclusions that can be drawn from the observations on the Nopparat Thara tidal flat are therefore limited.

1. The flat is inhabited, at least during part of winter, by a large population of $T$. duplicata.

2. The size distribution indicates that the population is composed of mature specimens and that juveniles are not present on the flat.

3. Specimens on the flat preferentially adopt a stationary, shallow infaunal, filter-feeding mode of life.

4. Two populations can be distinguished: a population of smaller specimens living preferentially near the beach and a population of larger specimens preferentially 
Fig. 8 Location of the studied section. a Geographical location of the section Sur Combe Ronde near Courtedoux in the Canton of Jura, Switzerland. b Palaeogeographical reconstruction of central Europe for the Late Kimmeridgian to Early Tithonian (modified after Thierry et al. 2000a, b)

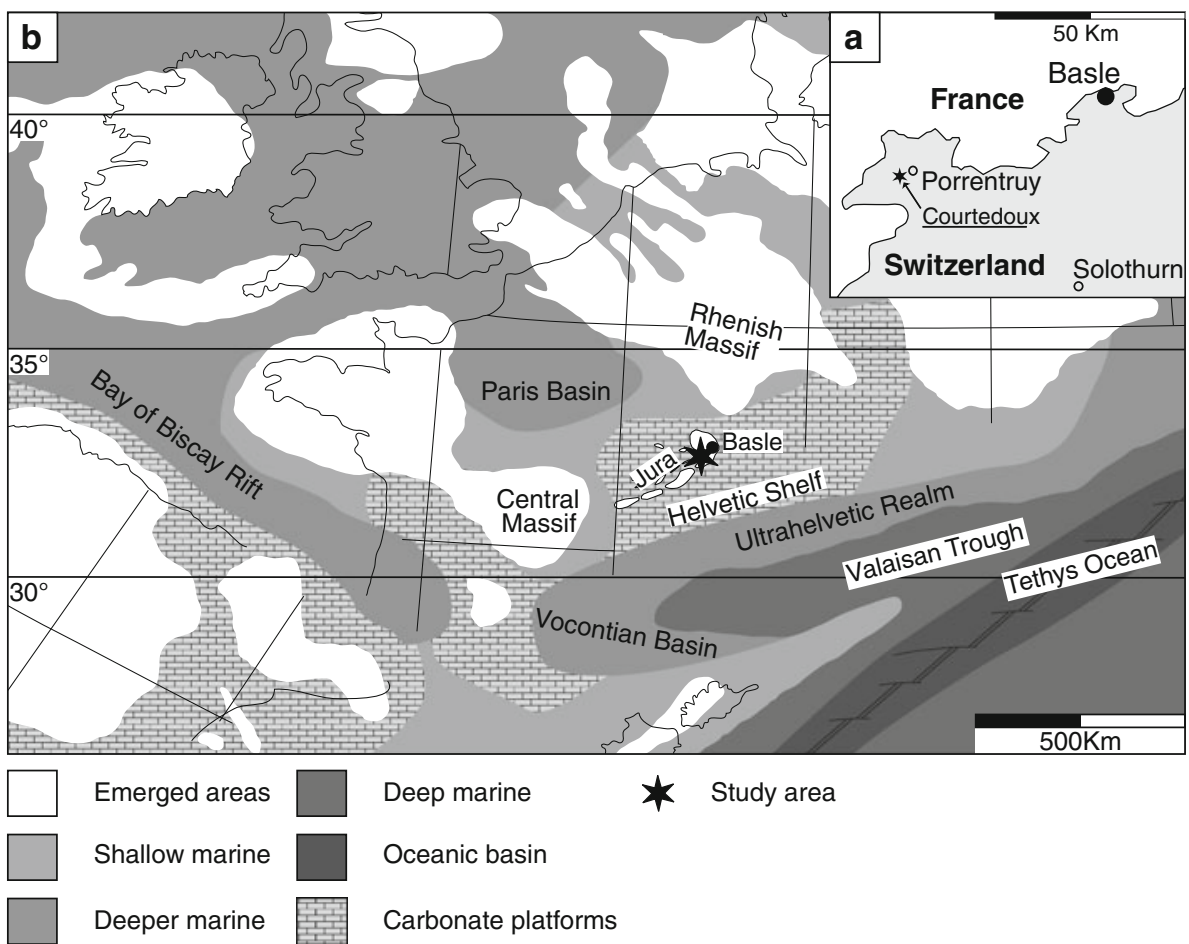

inhabiting the distal parts of the intertidal to marginal subtidal zones.

5. No turritellid specimens were found in the proximal subtidal firmground zone. However, the presence of shells of T. terebra may indicate that a further habitat exists in the distal subtidal zone.

6. Strong variations in accompanying fauna occur along the beach from east to west.

7. In the east, the shallow infauna is almost monospecific consisting of $T$. duplicata and the epifauna is mainly restricted to hermit crabs. In the west, only $2 \mathrm{~km}$ away in the same bay the fauna consists of a rich assemblage including corals and echinoderms.

\section{Geographical and geological setting of the Sur Combe Ronde section}

The Sur Combe Ronde section is located near the village of Courtedoux in the Canton of Jura, Switzerland (Fig. 8a; Swiss Coordinates: 568.869 / 250.082; World Geodetic System $847.026246^{\circ} \mathrm{E} ; 47.400821^{\circ} \mathrm{N}$ ). Ammonites found a few metres above the studied part of the section, especially in the "Marnes à Virgula" (Virgula Member s.l. of Gygi 2000a, b; northern Virgula Marls in Jank et al. 2006a; Virgula Marls in Jank et al. 2006b; lower Virgula Member in Colombie and Rameil 2007) indicate an early Late Kimmeridgian age in the Boreal Aulacostephanoides mutabilis or the Tethyan Aspidoceras acanticum ammonite zones, respectively (Jank et al. 2006b).
During the Kimmeridgian, the locality was situated at the northern margin of the oceanic Ligurian Tethys in the central part of the large, structurally complex Jura carbonate platform (Fig. 8b). The platform was further bounded by the Paris Basin in the northwest, the Rhenish Massif in the north and the Central Massif in the southwest. Palaeogeographic reconstructions show the platform at a palaeolatitude of $\sim 32^{\circ} \mathrm{N}$ (Thierry et al. 2000a, b). The marine fauna and flora indicate tropical-to-subtropical temperatures (Frakes et al. 1992). A semi-arid Mediterranean climate prevailed (Abbink et al. 2001; Rees et al. 2000, 2004). Numerous periods of emergence occurred over large areas of the northern Jura during the Kimmeridgian. These are evidenced by recurrent dinosaur track levels (Meyer 1993; Meyer and Thüring 2003; Marty et al. 2003; Marty 2008). The tracks of a diverse population of theropod and sauropod dinosaurs of different sizes, including post-hatchling individuals, have been recorded from the vicinity of Sur Combe Ronde. These tracks are interpreted as an in-situ population that lived on the carbonate platform (Marty 2008). This implies a local food source on the platform and, therefore, a substantial vegetation cover. Fossilized remains of this flora are being excavated from the Virgula Marls (Philippe et al. 2010). In the Late Kimmeridgian, the realm entered a time of increased subsidence estimated at $20-40 \mathrm{~m} / \mathrm{my}$ (Wildi et al. 1989). Moreover, most of the Kimmeridgian corresponds to a second-order transgression, which began in the Middle Jurassic and ended in the latest Kimmeridgian (e.g. Hardenbol et al. 1998; Hallam 2001; Colombie and Rameil 2007). Orbitally 
Fig. 9 Depositional model of the local environments on the Swiss Kimmeridgian carbonate platform reconstructed on the basis of the facies succession at Sur Combe Ronde and comparison to the Nopparat Thara tidal flat. a Schematic block model depicting the assumed terrace morphology due to differential subsidence. b Artistic model integrating different sedimentological and palaeoenvironmental features

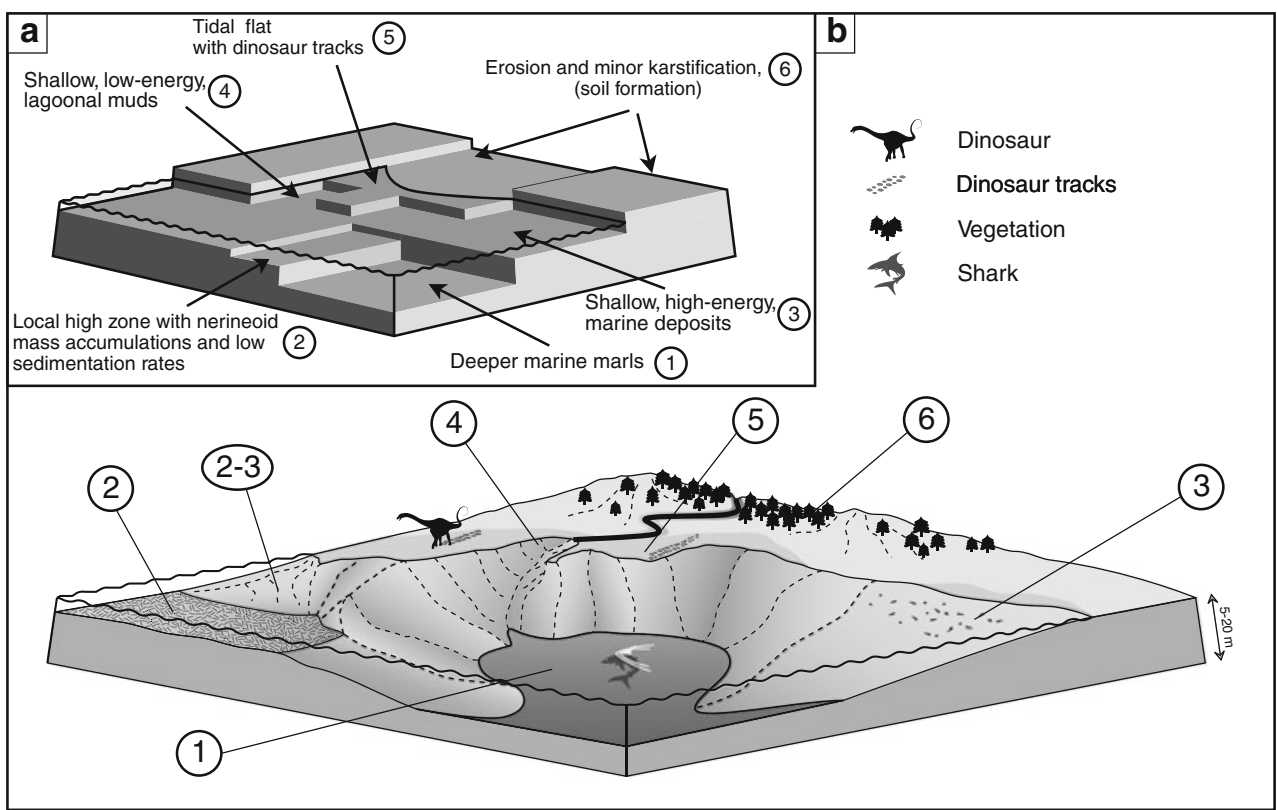

controlled high-frequency and low-amplitude sea-level changes were superimposed on the general transgressive trend (Colombié 2002; Strasser and Samankassou 2003; Colombie and Rameil 2007). Carbonate production on the platform kept up and sometimes outpaced sea-level rise filling in the accommodation space. Consequently, the depositional environments remained shallow and intertidal environments occurred at regular intervals. High-frequency regressional phases led to emergence, cementation, erosion and reworking of the previously deposited sediment (Fürsich 1979; Wright 1994; Strasser and Samankassou 2003). Sea-level changes and differential subsidence related to preexisting fault structures in the basement resulted in an irregular platform topography and variable facies patterns (Jank et al. 2006a). As a result, a highly structured platform developed, with individual blocks forming swells and depressions producing a discontinuous facies mosaic. A reconstruction of the depositional regimes on the platform based on the facies interpretation of the sedimentary record is depicted in Fig. 9.

\section{Description of the Sur Combe Ronde section}

For comparison with the Nopparat Thara tidal flat, the Sur Combe Ronde section was chosen, which has been studied and partially excavated for several years by the Paléontologie A16 (Fig. 10). Six genera of nerineoids have been described from the Sur Combe Ronde site (Waite et al. 2008). Ptygmatis (Sharpe 1850), Cryptoplocus (Pictet and Campiche 1862) and Eunerinea (Cox 1949), exhibit characteristic fold patterns. These three genera are known to form recurrent mass accumulations in the Late Jurassic of Swit- zerland, although they have not always been described under the same name (Thalmann 1966; Dauwalder and Remane 1979; Meyer 1990, 1993). At Sur Combe Ronde nerineoids occur at several different levels, the most conspicuous of these being a 1.5 -m-thick mass accumulation (Main Nerineoid Limestone Bed sensu Waite et al. (2008)) dominantly composed of Eunerinea (Fig. 10). Within this succession, discrete levels may be found where the dominance of Eunerinea is replaced by Ptygmatis (Waite et al. 2008). Above the mass accumulation nerineoids are generally less frequent. In this part of the succession Ptygmatis is absent and the assemblage is dominated by Pseudonerinea (de Loriol 1886), accompanied by Eunerinea, Cryptoplocus and possible Contortella (Pchelintsev 1965) (M.J. Barker, pers. comm. 2002). Itieria (Matheron 1842), which was also described from the assemblage, is now thought to be an erroneous determination. Molluscs in the Kimmeridgian of the Swiss Jura Mountains are generally not well preserved and only the internal casts remain of the nerineoid shells. No aragonite is preserved in the analysed material. All aragonite has been replaced by blocky calcitic spar during diagenesis. The original cross-lamellar shell structure of the nerineoids (Barker 1990) thus was destroyed, as the replacement of the shells was not structure preserving. Most of the information on the shell condition at the time of burial is therefore lacking. Occasionally micritic envelopes can be discerned under the microscope, which partially delimit the shell. Rarely, early diagenetic processes led to the cementation of the sediment prior to or contemporaneously to the dissolution of the aragonite. In these cases, the dissolved shell left a void, which was subsequently filled with micrite (Fig. 11a). In such cases, more information on the shell condition such as perforation is preserved. Encrustation of the shells is occa- 


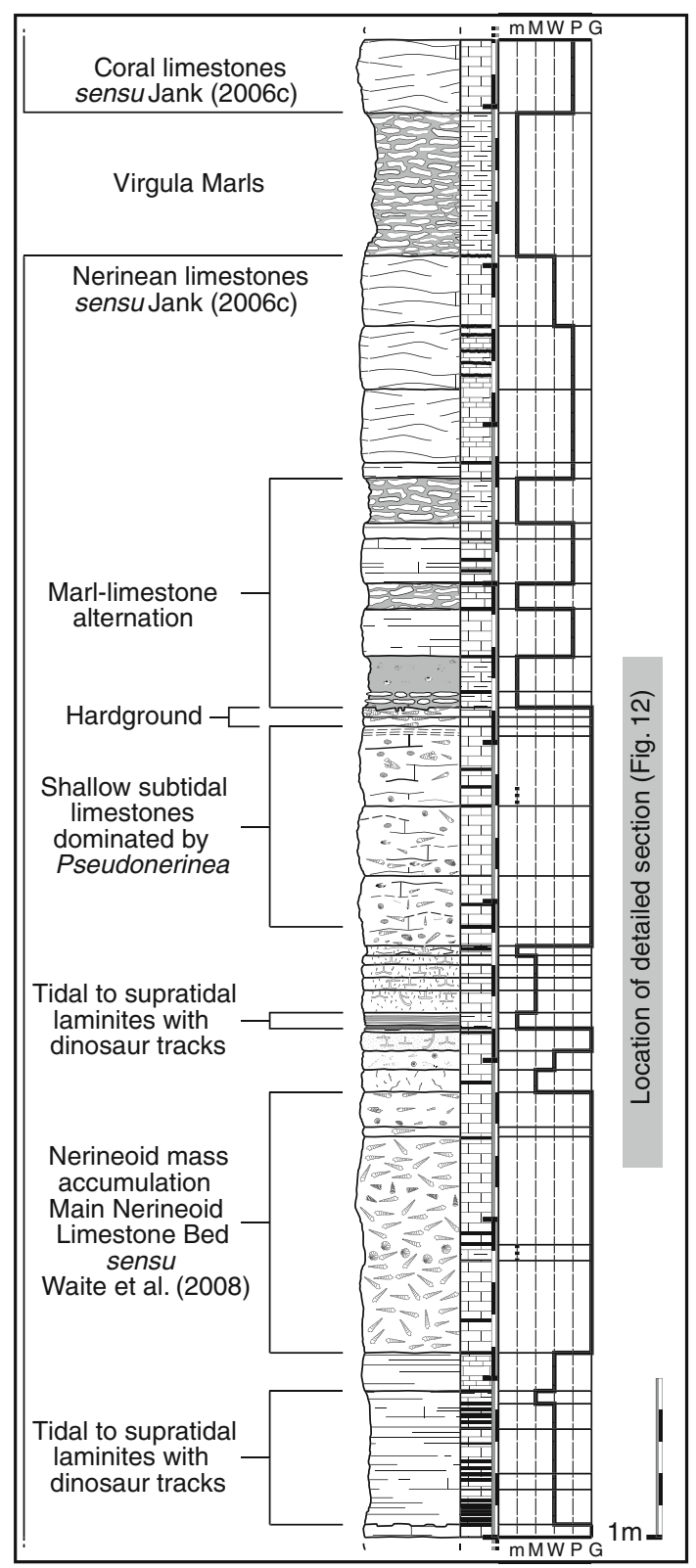

Fig. 10 Log of the Sur Combe Ronde section, recording the succession from the Main Dinosaur Level sensu Waite et al. (2008), intermediate levels sensu Marty (2008) to the first bed of the Coral limestones sensu Jank et al. (2006c)

sionally encountered and is restricted to serpulids, red algae (Marinella) and calcimicrobes (Fig. 11a). Primary thickness of the shells is often difficult to estimate as compaction has led to modifications of the casts and replaced shells (Fig. 11b). The nerineoid limestones are commonly massive hard rocks and preparation of the steinkerns is difficult. Although the shells are usually found preferentially oriented parallel to the bedding plane, a perfect cut through the spire of a shell providing a complete cross-section is hardly ever established, in polished section (Fig. 11b). Therefore, although the occurrence of the maximal shell size can be established the size of individual shells can at best be estimated. Small shells are problematic in any case as they may correspond to juvenile specimens as well as broken apical fragments of larger shells. However, small shells in the millimetre to centimetre range do not occur as a rule in the analysed rocks.

For this study, a 3-m-thick interval of the section was studied in detail bed by bed (Fig. 12; Legend in Fig. 13). In particular, the focus was laid on an interval dominated by the fold-free high-spired nerineoid genus Pseudonerinea (Fig. 14), which occurs together with the irregular echinoid genus Pygurus. The section is described from base to top.

The base of the detailed section, beds 18 and 17, is formed by a conspicuous mass accumulation of nerineoid gastropods of the genus Eunerinea usually embedded in a matrix of micritised peloidal grainstone. Only the top of this mass accumulation has been logged in the detailed section (Fig. 10). Bed 18 therefore is only the uppermost part of a 1.5-m-thick interval, which contains extremely high frequencies of Eunerinea, estimated at 7,000 specimens per $\mathrm{m}^{3}$, together with echinoderm remains, bivalve fragments and occasional corals (Waite et al. 2008). The unit is both under- and overlain by dinosaur track levels and records the deepest relative water conditions between the two emersion surfaces (Fig. 10). The matrix between the shells is composed of a micritised peloidal grainstone with abundant benthic foraminifera. Shell fragments are commonly overgrown by Marinella or calcimicrobes. Beds 18 and 17 differ slightly from the lower part of the mass accumulation in so far as the peloids are less micritised and the matrix contains abundant miliolid foraminifera. In bed 16, the number of nerineoids is reduced and Pseudonerinea replaces Eunerinea as dominant genus, although Eunerinea remains present. At the base of this bed, the miliolid abundance remains high but gradually decreases towards the top.

In bed 15 , the texture changes to mudstone. This bed contains no macrobenthos apart from occasional small, undetermined gastropods but is very rich in elongated, sparfiled, cavities and cracks. Birdseyes, remnants of algal mats and circum-granular cracks have been recorded from this level. Birdseyes are still present in bed 14 but there is no evidence of algal mats and the texture changes to a wackestone. The nerineoid genus Eunerinea reoccurs at this level. Beds 14 and 15 do not contain any echinoderm fragments.

Beds 13 and 12 contain neither micro- nor macrofossils but shallow Thalassinoides-type branching burrows in a grainstone texture are preserved in bed 13 and bed 12 shows a fine lamination. Peloids of different colour (white to yellowish beige) give the rock a mottled look. The top of bed 12 is trampled by both shallow theropod and sauropod tracks of varying sizes.

The track surface is covered by a succession of laminated marls and thin limestone layers (bed 11), which are 


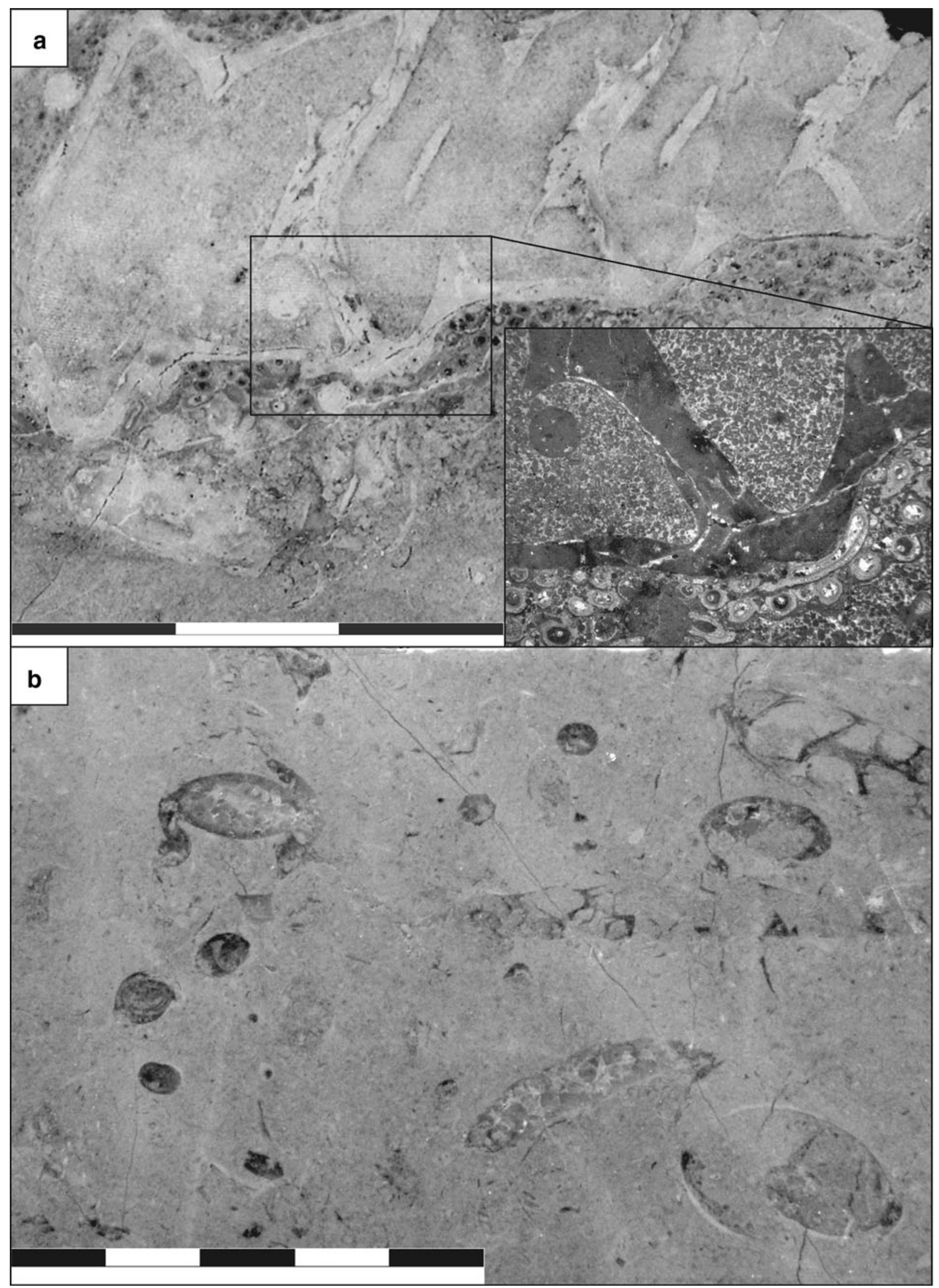


4 Fig. 11 Examples of preservation of nerineoid shells in the Sur Combe Ronde section. a Replacement of an Eunerinea shell by micrite; box shows a close-up of the serpulid encrusted exterior of the shell. b Polished section through a sample from bed 4 (see Fig. 12), showing numerous incomplete sections through Pseudonerinea shells partially deformed and replaced by blocky calcitic spar (scale in centimetres)

both free of macro- and microfossils except for the very top where a few benthic foraminifera and shell fragments occur. The laminites locally contain wave ripples as well as further dinosaur track levels including under- and overprints (Rameil 2005; Marty 2008). Some nerineoids especially of the genus Pseudonerinea but also Eunerinea have been recorded on the track surface. This is intriguing, as both the under- and overlying strata do otherwise not contain macrobenthos. These shells are infrequent and do not correspond to lag deposits. The laminites are covered by four thin beds of fossil-free mudstone (beds 10-7), which become thinner from base to top. These beds can be followed along the outcrop and show clearly defined surfaces.
They contain birdseyes and branching burrows filled with coarse-grained material, principally made up of peloids and echinoderm fragments. A fifth layer (bed 6), which contains the same sedimentary features but is more marly in composition tops this succession. The base of bed 5 marks a change in the depositional system. A diverse and dense accumulation of bivalve and gastropod shells in a bioturbated, peloidal grainstone rich in microfauna and echinoderm fragments is deposited over a sharp surface. This coquina can be traced for several square-kilometres and has a thickness of about $5-20 \mathrm{~cm}$. The shell accumulation is composed dominantly of the high-spired shells of the nerineoid genus Pseudonerinea but other gastropods and both articulated and disarticulated bivalve shells also occur. Some large articulated bivalves are filled with a material different from the encasing matrix. Encrustation of the faunal elements has not been observed. Additionally, black pebbles, vertebrate remains and intact gastropods of the delicate genus Herpagodes have been recovered from this layer (Daniel Marty, pers. comm. 2008). The basal coquina

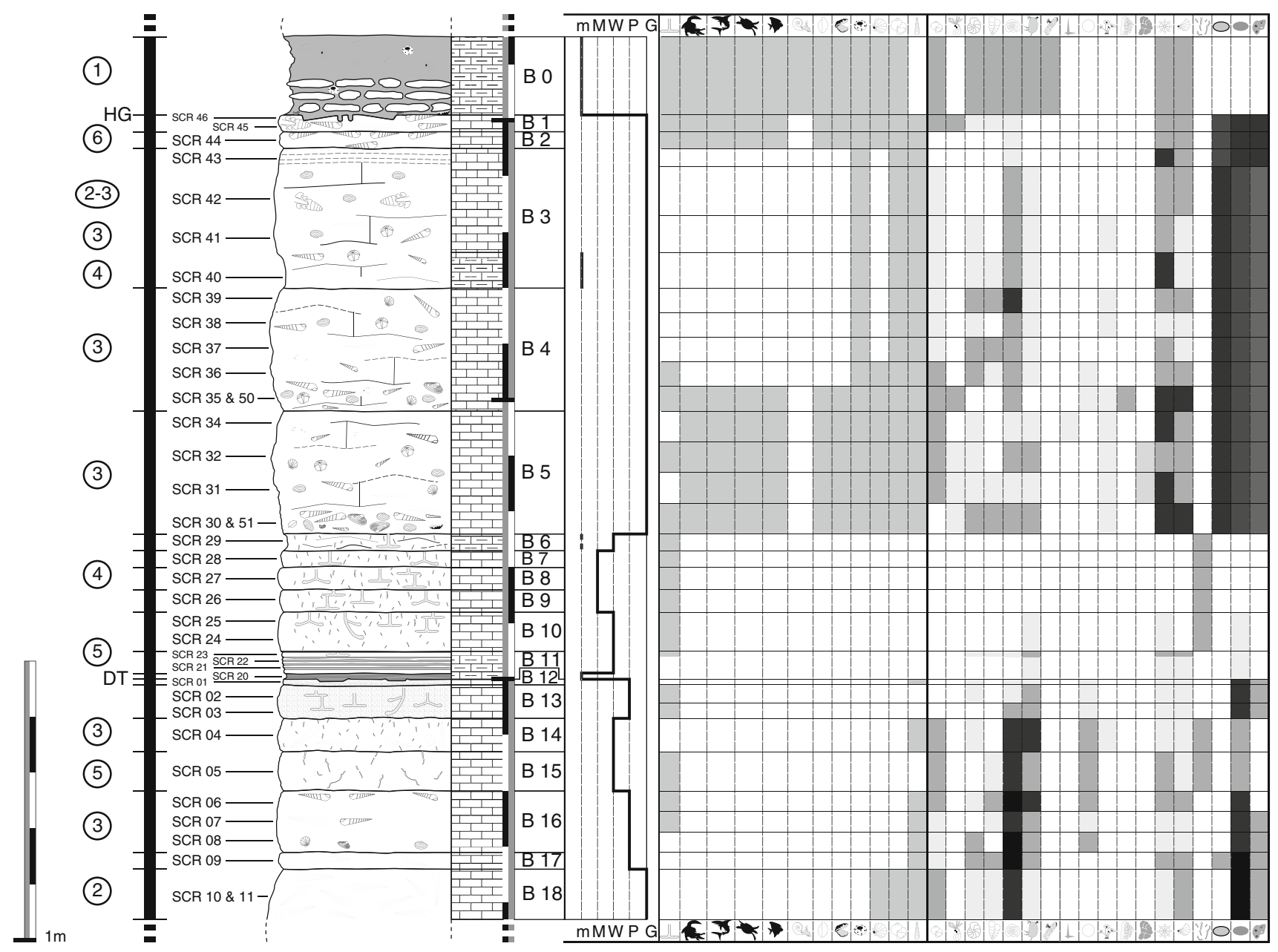

Fig. 12 Measured section at Sur Combe Ronde. Numbers in the first column to the left correspond to the depositional environments in Fig. 8. For legend see Fig. 13 


\begin{tabular}{|c|c|c|c|c|c|c|c|}
\hline Ma & $\begin{array}{l}\text { ofauna: } \\
\text { Crocodiles }\end{array}$ & $\mathrm{Mic}$ & $\begin{array}{l}\text { ofauna: } \\
\text { Small } \\
\text { gastropods }\end{array}$ & $\begin{array}{l}\text { Rel } \\
\text { (tota }\end{array}$ & $\begin{array}{l}\text { tive frequencies } \\
\text { thin section area') }\end{array}$ & $\begin{array}{l}\text { Sedi } \\
\text { lithol } \\
\text { comp }\end{array}$ & $\begin{array}{l}\text { nent structure, } \\
\text { ogy and } \\
\text { oonents: }\end{array}$ \\
\hline & Sharks & (8) & Plane-spiral & & Very abundant & 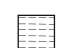 & Plane bedding \\
\hline & Turtles & & $\begin{array}{l}\text { toraminiters } \\
\text { Biserial }\end{array}$ & & Abundant & 聶 & Laminites \\
\hline & Fish & & foraminifers & & Frequent & 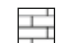 & Limestone \\
\hline & Cephalopods & (i) & $\begin{array}{l}\text { Miliolid } \\
\text { foraminifers }\end{array}$ & & Rare & 藏 & Marly \\
\hline & Brachiopods & 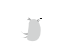 & Ostracodes & & $\begin{array}{l}\text { Present (macroscopic } \\
\text { assemblage) }\end{array}$ & & Limestone \\
\hline & $\begin{array}{l}\text { Oysters } \\
\text { Fchinoids }\end{array}$ & & Calcispheres & 0 & & & \\
\hline & & 2 & Green algae & $-e v$ & & 0 & Coated grains \\
\hline 8 & Gastropods & 2 & Red algae & DT & Dinosaur Track Level & - & Peloids \\
\hline & Nerineoids & 粗 & Calcimicrobes & $\mathrm{HG}$ & Hardground & $\therefore$ & Intraclasts \\
\hline & & 1 & Sclerites & Dur & lam Classification: & b & Burrows \\
\hline DIM & Eunerinea & (x) & Serpulids & M & Mudstone & 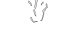 & Birdseyes \\
\hline 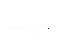 & $\begin{array}{l}\text { Eunerinea } \\
\text { Pseudonerinea }\end{array}$ & 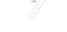 & Bryozoans & W & Wackestone & Beds & \\
\hline a(m) & $\begin{array}{l}\text { Pseudonerinea } \\
\text { Ptygmatis }\end{array}$ & $\varpi$ & $\begin{array}{l}\text { Oyster } \\
\text { fragments }\end{array}$ & $P$ & Packstone & B 4 & \\
\hline & Contortellatype & \% & $\begin{array}{l}\text { Echinoderm } \\
\text { fragments }\end{array}$ & & & & \\
\hline & Itieria & $\Delta$ & Shell fragments & SCR & & & \\
\hline
\end{tabular}

Fig. 13 Legend for Fig. 12

of bed 5 grades up into a less fossiliferous gastropod-rich peloidal grainstone with occasional disarticulated bivalve shells, brachiopods and well-preserved echinoids of the genus Pygurus. The dominant gastropod genus is Pseudonerinea. The population consists of similarly sized specimens and most complete specimens found throughout the section have an average spire height of $9 \mathrm{~cm}$ and a diameter of $1.5-1.7 \mathrm{~cm}$ at the base. The lower ten whorls can usually be discerned but the details of the upper whorls are invariably lost due to diagenesis and compaction. The extraction and preparation of elongated gastropod fossils from hard rock is extremely difficult, consequently complete fossils or polished sections through the spire are rare. Towards the top of the bed macrofossils become exceedingly rare but from the upper half of the bed sponge spicules have been recovered, which are not found throughout the rest of the section save for the deeper-water facies of bed 0 .

Bed 4 again begins with a basal coquina. This shell deposit, although it also contains rather large, thick-shelled bivalves, has not yielded articulated specimens and the majority of both gastropod and bivalve shells is worn. Many shell fragments are overgrown with calcimicrobes and embedded in a mixture of coated grains (micro-oncoids) and peloids. Again, the basal coquina grades into the peloidal gastropod- and echinoid-rich facies described for bed 5 . No change of facies is observed throughout the rest of the bed.

The base of bed 3 is formed by a layer of less cohesive limestone with irregular marl seams that is prone to weathering. The facies is mainly composed of peloids with rare disarticulated and fragmented bivalve shells and does not contain any complete macrofossils. The marl-rich base grades up into a gastropod- and echinoid-rich peloidal facies, which initially has the same characteristics as beds 5 and 4. However, Pseudonerinea is gradually replaced by Cryptoplocus as dominant nerineoid genus. Disarticulated bivalve shells are common and locally encrusted by serpulids. The top of bed 3 is characterised by a 5 -cm-thick interval of thin, plane-bedded layers of alternating coarse and fine grains with no macrofossils except for a few bivalve fragments. The bedding planes of the laminae are slightly oblique to the bedding planes of the over- and underlying beds.

Finally, beds 2 and 1 are formed by shell accumulations predominantly composed of Pseudonerinea with accompanying Cryptoplocus and Eunerinea. Both beds are of a dark reddish colour with a gradient towards a darker colour from the base of bed 2 to the top of bed 1. Rietveld refinement on XRD spectra of the matrix of these beds shows a goethite content of up to $7 \%$. The facies is a peloidal, coated-grain and intraclast grainstone with abundant bivalve and echinoderm fragments. The gastropod shells have been replaced by a white, fine-grained, porous, micritic material that contains up to $17 \%$ apatite but contains only up to $2 \%$ goethite forming a sharp colour contrast to the red matrix. This is a unique form of shell replacement as the aragonitic gastropod shells throughout the Kimmeridgian succession of the Swiss Jura are usually replaced by blocky calcitic

Fig. 14 Fossil steinkerns of the genus Pseudonerinea. a A cluster of prepared specimens from the "Banné Marls" several metres below the studied part of the Sur Combe Ronde section. b A partial specimen from bed 5 of the Sur Combe Ronde section. By courtesy of the Office de la culture-Section d'archéologie et paléontologie (OCC-SAP) (photo by Daniel Marty) 

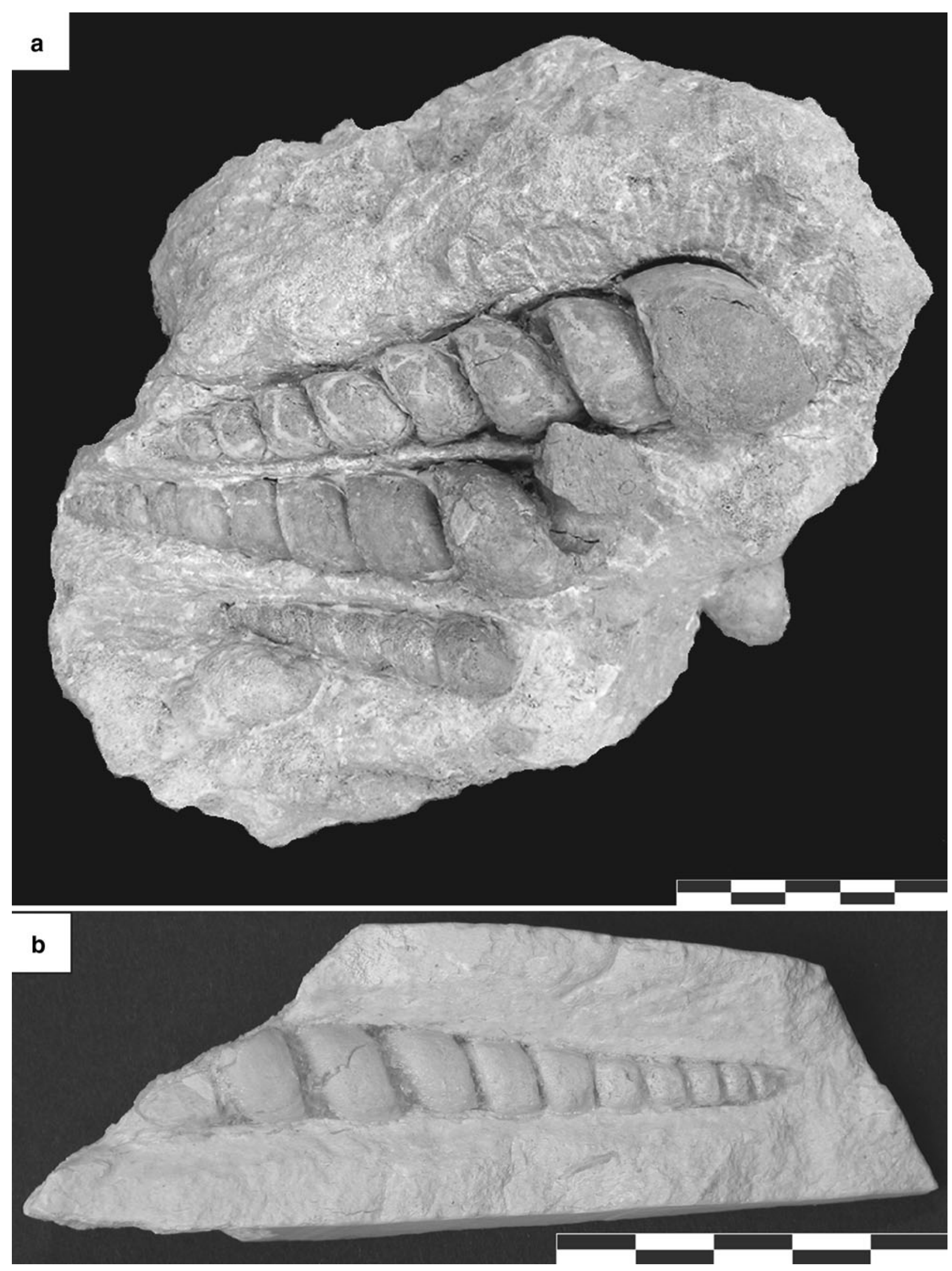


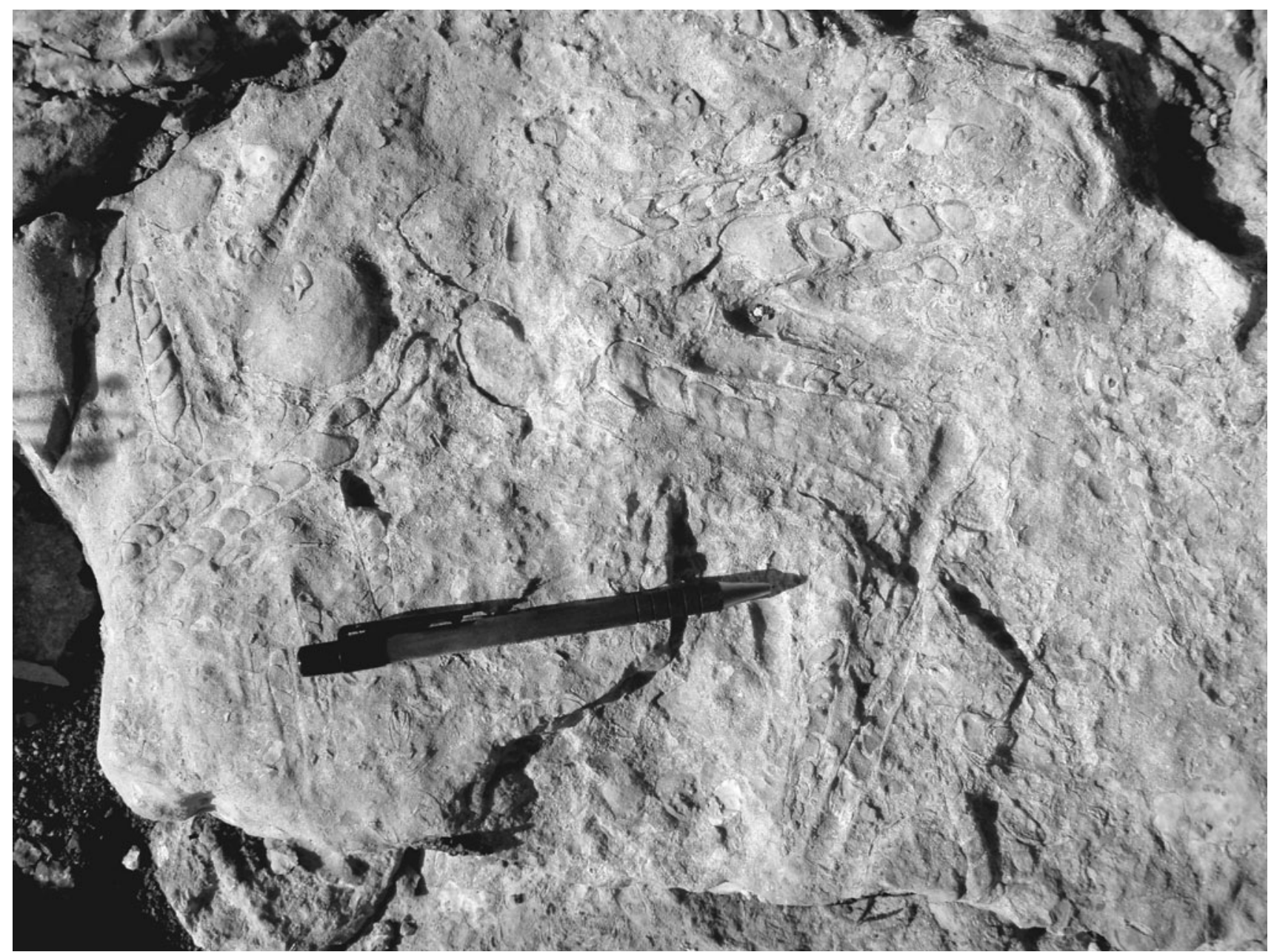

Fig. 15 Top of bed 2 of the Sur Combe Ronde section: weathered and slightly karstified surface. Pen is $\sim 14 \mathrm{~cm} \mathrm{long}$

cement. The nerineoid shells are of approximately equal size, around $8-10 \mathrm{~cm}$, when unbroken, and are commonly packed so densely that they touch each other (Fig. 15). The shells are preferentially bedded parallel or sub-parallel to the bedding plane but no clear indication of a preferential shell axis orientation has been discerned. Some shells are damaged or fragmented but articulated bivalve shells have been observed. In polished- and thin-sections, most shells show encrustation often both internal and external. The main encrusters appear to be serpulids.

In bed 0 the sedimentation pattern changes. It forms the first marl bed in a succession of marl-limestone alternations, which are characteristic for the top of the Nerinean Limestones sensu Jank et al. (2006c). The most prominent of these marl beds is the Virgula Marls, which marks the boundary between the Nerinean Limestones and the Coral Limestones (Fig. 10). This succession comprises coarsegrained bioclastic limestones and levels containing variable proportions of marls separated by bored and encrusted hardgrounds. The sediment contains glaucony giving these levels a greenish weathering colour. Bed 0 contains a rich vertebrate and invertebrate fossil record consisting of crocodilian, turtle, and fish remains (especially teeth) and skeletal elements of bivalves, gastropods, cephalopods, echinoids, brachiopods, foraminifera and ostracods. The dominant faunal element, however, is the small oyster Nanogyra sp. The base of the bed contains nodular limestone concretions and occasional lithified burrow systems of Thalassinoides.

\section{Interpretation of the palaeoenvironment of the Sur Combe Ronde section}

The formation of the nerineoid mass accumulation from Sur Combe Ronde and its palaeoecological significance has been discussed in detail in Waite et al. (2008). These authors concluded that a likely reason for the formation of the large and thick shells in nerineoids was related to counter predation when living on the sediment surface. As a consequence of the large shell, excess space in the spire was filled by the secretion of internal folds, and the early 
spire was frequently entirely plugged. This ensured that a small internal volume and hydraulic stability were maintained. Consequently, the long heavy shells impaired the mobility of the animals, and they are therefore believed to have adopted a semi-sessile life, feeding actively or passively off suspended food. During times of elevated labile organic carbon availability, large numbers of nerineoids colonised stable surfaces in agitated environments on topographical swells. The shells of the nerineoids acted as a sediment trap, thus producing an armoured carbonate accumulation. The recurrent nerineoid mass accumulations of the Late Kimmeridgian of the Jura Mountains are primarily formed by the genera Eunerinea, Ptygmatis and Cryptoplocus. The accumulations are dominated by one genus or the other presumably depending on environmental conditions such as water depth, physical energy within the habitat, sedimentation rate, substrate stability, and food supply. The Sur Combe Ronde mass accumulation is assumed to correspond to a maximum flooding deposit, as it records the relatively deepest water conditions between two emersion surfaces (Rameil 2005; Waite et al. 2008; Fig. 9). The habitat sustaining such vast populations of nerineoids is envisaged as an open terrace or local high zone in several metres of water depth where water energy was sufficiently high to uphold a continuous current supplying fresh food but not so strong as to perturb the position of the nerineoids. Constructive micritic envelopes and common algal overgrowth seem to indicate a reduction in sediment deposition possibly due to a bypass situation (No. 2 in Fig. 8).

The reduction in the amount of micritisation in the uppermost part of the mass accumulation may reflect a change in the environmental conditions to a higher rate of sedimentation and more mobile substrate at the top of this unit. The change in texture in bed 15 and the birdseyes indicate a tidal-flat environment, some of the elongated, sparfilled voids are thought to correspond to worm burrows. The transition from bed $18-15$ is interpreted as a shallowing-up succession from the submarine terrace (No. 2 in Fig. 8) to a high-energy tidal flat corresponding to depositional condition No. 3 in Fig. 8, and finally a low energy tidal flat in bed 15 corresponding to depositional condition No. 5 in Fig. 8. The reoccurrence of Eunerinea in Bed 14 and the wackestone matrix indicate a brief increase in water-energy and slightly deeper depositional conditions between the under- and overlying shallow-water deposits. The composition of the microfacies in Beds 12 and 13 is similar. The evolution from bioturbation to lamination to dinosaur track preservation indicates a succession from marginal-marine to tidal-flat to supratidal-flat environment during relative sea-level fall. Bed 12 and the overlying succession of marly laminites (bed 11) are interpreted as intertidal to supratidal regime (Pratt and James 1986; Marty 2008) and correspond to depositional condition No. 5 in
Fig. 8. The single, large and heavy gastropod shells, which are only found at the top of bed 12 , are normally associated with fully marine conditions. Therefore, they likely document episodes of strong swell or storms when shells could be transported relatively far onto the flat. A detailed sequence- and cyclostratigraphical analysis of the section has shown that this surface represents the boundary of a small-scale sequence that formed in tune with a 100-kyr orbital eccentricity cycle (Rameil 2005).

Beds 10-6, which form a thinning-up succession, are interpreted as a mudbank deposited in a protected environment (No. 4 in Fig. 8; Tedesco and Wanless 1991). The birdseyes are assumed to represent remnants of stabilizing algal mats that allowed the preservation of the bank during storm events while the thinning-up of the beds reflects the top of the mudbank approaching the water surface and depositional depth becoming progressively shallower. Stratification and thinning-up in this unit therefore likely reflect an autocyclic process generated by episodic sedimentation and shallowing-up (Pratt and James 1986; Tedesco and Wanless 1991). The coarse grainstone infills of the burrows are interpreted as tubular tempestites, which were deposited only in the burrows during periodic storm events (Wanless et al. 1988; Tedesco and Wanless 1991). For the coquina of bed 5 , a complex history must be invoked since it shows features of condensed, compound and lag deposits (Kidwell 1991). It is not clear from the field observations if the base is erosional but the obvious change in grain size and the sharp surface indicate a change to a high-energy system. The transported bivalves, which are not in life position, may indicate storm deposition. The black pebbles indicate coastal erosion during relative sea-level rise (Strasser 1984). The deposit would therefore be categorized as a transgressive lag (Kondo et al. 1998) yet the shell destruction and encrustation commonly associated with such a deposit (Kidwell 1991) is lacking. Therefore, the coquina is interpreted as a complex composite storm accumulation formed during transgression, which possibly underwent repeated burial (Kidwell 1991; Meldahl 1993). The overlying gastropod and infaunal echinoid-rich assemblage is suggested to correspond to a shallow subtidal habitat with mobile sediment in agitated water similar to that on the Noparat Thara Beach (depositional environment No. 3 in Fig. 8). The encrustation and wear of the shells in the overlying Bed 4 indicates a rather long residence time at the sediment-water interface and/or reworking of older deposits. This level is less continuous in the field and may represent a local lens. Although it shows characteristics of both storm and transgressive lag deposits, the stratigraphical position favours a transgressive context. It is, therefore, interpreted as a transgressive lag deposit formed during a pulse of sea-level rise. Again, it grades into the shallow subtidal facies of bed 5 . The marl-rich base of bed 3 is 
interpreted as a shallow semi-protected deposit of alternating water-energy with grainstone and clays being deposited successively. The change in facies is assumed to be sealevel induced and related to a phase of relative sea-level fall, which led to the temporarily protected environment. Although the central part of bed 3 has a similar grain size distribution as the underlying beds 4 and 5 , the large and probably epifaunal nerineoid genus Cryptoplocus, which replaces Pseudonerinea as dominant genus at this level, as well as the incrustation of the shells may indicate a temporary stabilisation of the substrate (Wieczorek 1979). Cryptoplocus is known to form mass accumulations, which are associated with stable substrate conditions and low sedimentation rates. This is change, therefore, potentially reflects reduced sedimentation rates permitting its colonization by a different community. The plane-bedded top of bed 3 with its alternating lamina of different sized grains is interpreted as a beach deposit.

Beds 2 and 1 are almost identical in facies. They are separated by a thin joint of marls and together form a deposit approximately $10 \mathrm{~cm}$ thick. They comprise an accumulation of shells, which is bounded both at the base and the top by emersion surfaces. At an outcrop $500 \mathrm{~m}$ further to the north, a layer of moderately rounded, centimetre-sized micritic pebbles forms the base of bed 2 . These are thought to be produced by reworking of a low-energy deposit. The dominating large and relatively complete gastropod shells and partially articulated bivalve shells could be concentrated by gentle winnowing and washout of the finer sediment fraction. The rather prominent encrustation with serpulids, of several faunal elements retrieved from this deposit, and the heavily bioturbated texture of the double bed, indicates a prolonged residence time at the sediment water interface. The coquina is thought to resemble a composite accumulation likely formed by numerous processes over a relatively long period of time (Kidwell 1991; Meldahl 1993) but ultimately leading to a concentration of relatively coarse elements in a grainstone facies. The formation of a first generation of micritic meniscus cements may indicate an initial submarine stabilisation and cementation due to the growth of algal filaments (Hillgärtner 1998). The top of bed 1 shows grooves or karren, which resemble minor karstification, and some nerineoid steinkerns have been eroded out of the surface leaving conical depressions. The molluscan fossils can be easily distinguished as the softer micritic phase that replaced the shell preferentially weathers down and the remaining steinkerns form a positive relief (Fig. 13). The karstification and the dissolution of the aragonitic shells are interpreted as early diagenetic features of a subaerially exposed environment. The iron impregnation is believed to be related to the formation of a soil cover during emersion (Hillgärtner 1998; Henning-Fischer 2003; Merino and Banerjee 2008; Reolid et al. 2008). Mildly acidic soils, which are buffered by the underlying limestone, conserve iron-rich minerals (Retallack 1990), which can explain the goethite impregnation and subsequent red staining of the beds. Therefore, the overlying soil would have been a type of terra rossa, which is typically found on limestones in semi-arid to sub-humid climates. Several authors have proposed an arid to semi-arid Mediterranean climate for the period of the Late Kimmeridgian of Western Europe with strong seasonality (Moore et al. 1992; Hallam 1993; Abbink et al. 2001). In the absence of a local siliciclastic source and accumulation by alluviation, most of the non-carbonate fraction in soils is derived from aeolian dust (Wright 1994). During the Late Jurassic, the interiors of the large continental blocks experienced harsh, arid conditions (Hallam 1993) and would have formed potential source areas for aeolian dust. Recent findings of floral remains in the Virgula Marls (Waite et al. 2009) confirm the idea that vegetation was present on the platform and imply soil formation. However, no palaeosols have been reported from the Late Kimmeridgian Jura platform.

As no palaeosols are preserved but the existence of soils is implied from the abundance of dinosaur tracks and plant remains in the marls, such soils must have been eroded during subsequent pulses of relative sea-level rise. The erosive features at the top of bed 1, such as the conical shaped depressions, are attributed to this phase of wave action during re-flooding (Fürsich 1979; Wright 1994; Hillgärtner 1998). The karstified, iron-impregnated surfaces of beds 2 and 1 are interpreted as the bedrock metasomatic zone of an eroded palaeosol (Merino and Banerjee 2008; Meert et al. 2009; No. 6 in Fig. 8).

Finally, after reflooding, the karstified surface of bed 1 for a time formed a hardground, which was perforated by boring organisms of the Trypanites suite and encrusted by oysters. This phase is interpreted as a time of non-deposition, possibly due to elevated currents in the breaker zone. Later, the Trypanites burrows and shell voids were filled by a porous, apatite-rich micritic phase. SEM micrographs of the filling show neoformation of crystals indicating that this phase was at least partially precipitated from the pore water. The difference in the goethite content of the infill of the burrows and the impregnated hardground indicates that the precipitation of the apatite-rich filling postdated the goethite impregnation of the hardground and predated the covering of the hardground by the marls. Finally, a marldominated sedimentary regime established itself (bed 0 ). Initially, the sedimentation rate was low and a condensed section formed above the hardground. It is characterised by the abundance of skeletal remains of turtles, crocodilians and fishes (above all teeth of pycnodontid fish). Subsequently, sedimentation picked up and dark oyster-rich marls were deposited within the storm-wave influenced zone (Jank et al. 2006c). The diverse vertebrate and invertebrate 
fauna including ammonites and nautilids is interpreted as an open-marine deeper-water environment corresponding to depositional condition No. 1 in Fig. 8. The clays may at least partially be derived from the eroded soils that previously covered the emerged platform. The illite, smectite and I/S-mixed layer dominated composition of the clay mineral assemblage discussed in Marty (2008) may indicate a warm monsoon-like climate with pronounced seasonal variations in precipitation (e.g. Raucsik and Varga 2008). However, further palaeoenvironmental interpretations are disregarded at present as the provenance of the clays cannot be unequivocally established.

\section{Discussion}

The diagnostic taxonomic characters of the superfamily Nerineoidea are the presence of a heterostrophic protoconch, a juxtasutural selenizone (slitband), and a rudimentary siphonal canal (Barker 1990, 1994). Turritellids on the other hand have a homoeostrophic protoconch, do not possess a slitband and only some forms display a siphonal canal (Tichy 1980; Ziegler 1992; Squires and Saul 2007). For a full anatomical description of shapes and characteristics of turritellids and nerineoids, see Wenz (1938) and Moore and Pitrat (1960). The taxonomic relationships of the Nerineoidea to other clades of the Gastropoda are highly complex, inconsistent and, to a certain extent, speculative. For a few nerineoid genera, a heterostrophic protoconch has been ascertained (Moore and Pitrat 1960; Barker 1994). This fact has led the Nerineoidea to be placed in the order Heterostropha (e.g. Saul and Squires 2002). Heterostropha is itself included into the Heterobranchia (Gray 1840; Ponder and Lindberg 1997; Bouchet and Rocroi 2005). Thus nerineoids would be related to the Acteonidea or Pyramidelloidea (Moore and Pitrat 1960). They have certainly been reported from deposits where they are associated with these taxa (Zeuschner 1849; Allison 1955; Herm 1977). Alternatively, Wenz (1938) placed the superfamily Nerineoidea including his family Ceritellidae (Tubiferidae), which comprises the genus Pseudonerinea, in the Prosobranch order Entomotaeniata. Sirna (1995) also related the Nerineoidea to the Prosobranchia and referred to them as characteristic mesogastropods.

Turritellids were also originally placed in the Mesogastropoda (Moore and Pitrat 1960; Allmon 1988). However, the more recent classifications place the Turritellidae (Lovén 1847) in the superorder Caenogastropoda and the superfamily Cerithioidea, whereas the nerineoids remain in the Heterobranchia. Pchelintsev (1965) stated that the highspired Mesozoic families were derived from different phylogenetic branches of the Murchisoniacea and that therefore, they comprised a uniform genetic group. In his proposed order of Murchisoniata he included several related taxa including Nerineoidea, Turritellidae, Potamididae and Cerithiidae. At least for the Cerithioidea, this was partially confirmed by Ziegler (1983). Thus, the nerineoids would appear to be distant relatives of such high-spired forms as the cerithids and turritellids. Herm (1977) found nerineoids together with cerithioids and therefore surmised that their ecology was comparable. Dauwalder and Remane (1979) deduced that the ecology of nerineoid mass accumulations was similar to that of oysters. Waite et al. (2008) compared the palaeoecology of nerineoids to that of rudists based on their close association in some environments and their similar baffling behaviour. Several works document the co-occurrence of turritellids and nerineoids in the same and adjacent beds (Zeuschner 1849; Allison 1955). Moreover, both turritellids and nerineoids are reported from Cretaceous deposits adjacent to occurrences of small oysters (different types of Exogyra) in the Cretaceous of North America (Allison 1955; Allmon and Knight 1993). Similarly, nerineoids are found in the lateral equivalents of oyster (Nanogyra virgula) beds in the Jurassic of Switzerland (Jank 2006a).

Finally, Allison (1955) described abundant turritellids occurring together with abundant Pseudonerinea adjacent to nerineoid mass accumulations and oyster beds in the Middle Cretaceous of Mexico. The deposits found in the Jurassic of Switzerland, which document a faunal composition before the Cretaceous rise of the turritellids, show the same association where beds dominated by Pseudonerinea are adjacent to nerineoid mass accumulations, which grade into marly oyster-dominated environments. In summary, turritellids and nerineoids are two very diverse clades, which had common ancestors. Several genera within these clades have large, high-spired shapes with similar apical angles and some genera show similar apertural features. Filling of the apex with secondary carbonate septa in large gerontic specimens is common in both taxa (Wieczorek 1979; Signor 1982) as is gregarious behaviour and occurrence of mass accumulations in carbonate rocks. This has led to the assumption that, like turritellids, nerineoids are likely to have predominantly remained stationary. During the Jurassic, the nerineoids dominated the shallow epeiric environments. In the Cretaceous, nerineoids and turritellids occurred together in such ecological systems and from the Maastrichtian onwards the turritellids became the dominant form.

There can be no doubt that the Recent Andaman Sea coast and the ancient Kimmeridgian platform are two very different sedimentary systems. The Andaman coast is dominated by siliciclastic input and a humid tropical climate while the Kimmeridgian platform was a vast, shallowmarine carbonate system with little continental input and an assumed warm semi-arid climate (Abbink et al. 2001; Rees 
et al. 2000; 2004). Nevertheless, the Andaman coast of Thailand is rather gently inclined and forms large shallowmarine areas and tidal flats. The Phang Nga Bay can therefore morphologically and topographically (excepting the tower karst) be assumed to reflect similar conditions as prevailed on the Kimmeridgian carbonate platform.

The entire Phang Nga Bay is less than $100 \mathrm{~m}$ deep and locally much shallower. Off the coast of Krabi, especially adjacent to the islands, water depth is commonly around $20 \mathrm{~m}$. Corals range from the intertidal to these depths and coral carpets associated with mud facies are typical for the area. Depositional water depth and mud input correspond to the conditions inferred for the marl deposits in the Kimmeridgian succession. Invertebrate population, however, differs considerably as corals are rare in the studied Kimmeridgian succession of the Swiss Jura.

Low-energy tidal flat environments are also common in east-facing bays on the Krabi coast. Decimetre-thick packages of intertidal algal laminites in mud facies are found in the low-energy bay of Railay East (Fig. 1). Unfortunately, most of the coastline has been modified, and it is not clear weather supratidal flats originally existed. Certainly in some areas mangrove swamps are still preserved although most of these have apparently been destroyed in favour of tourist beaches.

The predominant lithology of the bedrock on the Krabi coast is limestone and the tower karst is the dominant landscape-forming feature. Wave-cut terraces are common along the Krabi coast as for example at the locality Ban Laem Pho (Fig. 1). Thus several elements interpreted for the Sur Combe Ronde section can be found closely spaced along the Phang Nga Bay coast.

Some depositional regimes of the Kimmeridgian platform and the Andaman coast are similar while others are less congruent. In this context, the tidal flat of Nopparat Thara, habitat of the extant gastropod T. duplicata is compared to the Pseudonerinea-dominated succession of beds 5-3 at Sur Combe Ronde. When comparing the shells of these two forms (Figs. 4, 14), it is readily apparent that the two species are similar with respect to their size, apical angle $\left(\sim 22^{\circ}\right.$ for Pseudonerinea; $\sim 24^{\circ}$ for the measured specimens of $T$. duplicata) and high-spired morphology. Comparative morphology of nerineoids such as Pseudonerinea with different species of recent endobenthic highspired gastropods has led to the assumption that Pseudonerinea had an at least partially infaunal mode of life (Barker 1990).

Sedimentary features of the succession of beds $5-3$, such as grain size distribution (Fig. 2c, d), lag deposits and the plane-bedded beach deposit are comparable to the littoral facies of the high-energy, open-marine environment of Nopparat Thara. Similarities are also evident when considering the faunal composition of the Recent and the fossil counterparts. The irregular echinoid Pygurus shows morphological modifications, which imply an adaptation towards a burrowing mode of life (Saucede et al. 2007). Pygurus has also been reported from similar shallowmarine environments on the adjacent Mesozoic Swiss Helvetic shelf (Fig. 7b), where it occurs in coarse-grained cross-bedded sandy carbonates (e.g. Föllmi et al. 2007). It is therefore assumed that Pygurus occupied a similar ecological niche on the Kimmeridgian carbonate tidal flats as do the modern sand-dollars of the genus Clypeaster on the Nopparat Thara tidal flat.

At Sur Combe Ronde, the interval dominated by Pseudonerinea is found under- and overlain by unequivocal indicators of emersion. The grainstone texture, the underlying lag deposits and the overlying plane-bedded sediment structures indicate a high-energy environment. The dominance of semi-infaunal nerineoids and echinoids with accompanying bivalves and a sandy matrix lead to the assumption that this environment was similar in energetic conditions to those found on the Nopparat Thara tidal flat. The similarity of the habitat and faunal composition indicate that the mode of life of Pseudonerinea may be compared to that of $T$. duplicata. Direct comparison of shape, size and environmental conditions lead to the conclusion that Pseudonerinea was a semi-infaunal, suspension-feeding genus inhabiting mobile sediment in a high-energy environment and thus occupied a similar ecological niche as T. duplicata today. A suspension-feeding mode of life is also assumed for the nerineoid mass accumulations (Waite et al. 2008). The extraordinary numbers of individuals found in these beds imply an external source of food (Saul and Squires 2002). The nutritional basis for sustaining suspension-feeding gastropods in a semi-arid carbonate environment can be partly accounted for by runoff from the emerged parts of the platform during the wet season. Furthermore, marine productivity may be induced by the input of aeolian dust into the system. In particular soluble $\mathrm{Fe}^{2+}$ has been shown to be an important factor for enhancing marine phytoplankton productivity (e.g. Martin 1990). Considerable supplies of arid aeolian dust originating from the interior of the large continents have been postulated by Hallam (1993). In the generally transgressive context of the studied Kimmeridgian deposits, erosion and reworking of organic-rich soils is also thought to have been a major process for supplying suspended food into the platform waters.

\section{Conclusions}

1. In the absence of any behavioural data for nerineoids, the herein presented data on T. duplicata may tentatively serve as reference values for comparable nerineoids such as Pseudonerinea. 
2. The shells of the nerineoid genus Pseudonerinea and the turritellid species $T$. duplicata show a high-spired morphology with similar size ranges and a similar apical angle.

3. Both forms inhabit mobile sandy tidal flat environments in shallow, warm, high-energy waters.

4. Both forms occur with a similar accompanying fauna especially regarding the occurrence of infaunal echinoids.

5. A similar mode of life is therefore suggested for both forms. This supports the hypothesis of a primarily suspension-feeding mode of life for large high-spired nerineoids.

6. Suspended food is scarce in extant oligotrophic carbonate environments where supply of nutrients from rivers is negligible. Therefore, runoff, enhanced marine productivity in connection with the supply of iron-rich dust and coastal erosion of organic rich soils during transgression are proposed to be the primary source of suspended organic material on the Swiss Kimmeridgian platform.

7. Erosion of the emerged platform during transgression effectively removes any existing soil covers, flushing clays and organic particles into the adjacent deeper realms of the platform. The existence of soils is invoked from the recurrent occurrence of plant remains and dinosaur tracks, which indicate a vegetation cover.

Acknowledgments Very special thanks go to Warren D. Allmon for supplying literature and for his continued interest in the project, and to Henk Dekker for sharing his extensive knowledge and experience on the turritellids of Thailand. Special thanks also go to Ben Boo for his interest and sharing of information. Further special thanks go to Somwang Patamakanthin and Guido Poppe for their interest and their letters of introduction. We would also like to thank Jörn Geister for sharing his knowledge and literature and interesting discussions. A special thanks go to the Paléontologie A16, especially Daniel Marty, for their continued collaboration and invaluable support. Thanks also go to the reviewers Matías Reolid and an unknown reviewer for very helpful input. Finally, we would like to acknowledge the Swiss National Science Foundation (Project 20-109214.05) for financing this study.

\section{References}

Abbink O, Targarona J, Brinkhuis H, Visscher H (2001) Late Jurassic to earliest Cretaceous palaeoclimatic evolution of the southern North Sea. Glob and Planet Change 30:231-256

Adams A, Reeve LA (1848-1850) Mollusca. In: Adams A (ed) The Zoology of the Voyage of H. M. S. Samarang, under the Command of Captain Sir Edward Belcher, C. B., F. R. A. S., F. G. S., During the Years 1843-1846. London Part 1: X + [II] + 24 pl. 19 [November 1848]. Part 2

Allison EC (1955) Middle Cretaceous gastropoda from Punta China, Baja California, Mexico. Paleontol 29:400-432

Allmon WD (1988) Ecology of Recent turritelline gastropods (Prosobranchia, Turritellidae); current knowledge and paleontological implications. Palaios 3:259-284
Allmon WD (1992) Role of temperature and nutrients in extinction of turritelline gastropods; Cenozoic of the northwestern Atlantic and northeastern Pacific. Palaeogeogr Palaeoclimatol Palaeoecol 92:41-54

Allmon WD (1994) Patterns and processes of heterochrony in lower Tertiary turritelline gastropods, U.S. Gulf and Atlantic coastal plains. J Paleontol 68:80-95

Allmon WD (1996) Evolution and systematics of Cenozoic American Turritellidae (Gastropoda). 1. Paleocene and Eocene species related to "Turritella mortoni Conrad" and "Turritella humerosa Conrad" from the US Gulf and Atlantic Coastal Plains. Paleontogr Am 59:7-134

Allmon WD (2007) Cretaceous marine nutrients, greenhouse carbonates, and the abundance of turritelline gastropods. J Geol 115:509-523. doi:10.1086/519775

Allmon WD, Cohen PA (2008) Palaeoecological significance of turritelline gastropod-dominated assemblages from the mid-Cretaceous (Albian-Cenomanian) of Texas and Oklahoma, USA. Cretaceous Res 29:65-77. doi:10.1016/j.cretres.2007.04.001

Allmon WD, Harris WB (2008) A new species of turritelline gastropod from a turritelline-dominated limestone in the Paleocene of North Carolina. J Paleontol 82:442-446

Allmon WD, Knight JL (1993) Paleoecological significance of a turritelline gastropod-dominated assemblage in the Cretaceous of South Carolina. J Paleontol 67:355-360

Allmon WD, Jones DS, Vaughan N (1992) Observations on the biology of (Prosobranchia: Turritellidae) from the Gulf of California. Veliger 35:52-63

Allmon WD, Jones DS, Aiello RL, Gowlett-Holmes K, Probert PK (1994) Observations on the biology of Maoricolpus roseus (Quoy-and-Gaimard) (Prosobranchia, Turritellidae) from NewZealand and Tasmania. Veliger 37:267-279

Arua I (1989) Gastropod predators and their dietary preference in an Eocene molluscan fauna from Nigeria. Palaeogr Palaeoclimatol Palaeoecol 72:283-290

Arua I, Hogue M (1989) Fossil predaceous gastropod borings from Nigeria. Palaeogeogr Palaeoclimatol Palaeoecol 73:175-183

Barker MJ (1990) The palaeobiology of nerineacean gastropods. Hist Biol 3:249-264

Barker MJ (1994) The biostratigraphic potential of Nerineacean gastropods - case studies from the Middle Jurassic of England and the Upper Jurassic of France. Geobios 17:93-101

Bax NJ, Mcennulty FR, Gowlett-Holmes KL (2003) Distribution and biology of the introduced gastropod, Maoricolpus roseus (Quoy and Gaimard, 1834) (Caenogastropoda: Turritellidae) in Australia. Centre for Research on Introduced Marine Pests. Technical Report 25:1-32

Bouchet P, Rocroi J-P (2005) Classification and nomenclature of gastropod families. ConchBooks, Hackenheim

Cadée GC, Walker SE, Flessa KW (1997) Gastropod shell repair in the intertidal of Bahia la Choya (N. Gulf of California). Palaeogeogr Palaeoclimatol Palaeoecol 136:67-78

Carpenter KE, Niem VH (ed) (1998) FAO Species identification guide for fishery purposes, The living resources of the Western Central Pacific, vol 1. Seaweeds, corals, bivalves and gastropods. Food and Agriculture Organisation of the United Nations, Rome

Colombié C (2002) Sédimentologie, stratigraphie séquentielle et cyclostratigraphie du Kimméridgien du Jura Suisse et du Bassin Vocotien (France): relations plate-forme-bassin et facteurs déterminants. Dissertation, Geofocus 4, University of Fribourg

Colombie C, Rameil N (2007) Tethyan-to-boreal correlation in the Kimmeridgian using high-resolution sequence stratigraphy (Vocontian Basin, Swiss Jura, Boulonnais, Dorset). Int J Earth Sci 96:567-591. doi:10.1007/s00531-006-0117-3

Cox LR (1949) On the genotype of Nerinea; with a new subgeneric name Eunerinea: Malac. Soc Lond Proc 27:248-250 
Dauwalder P, Remane J (1979) Etude du Banc a Nerinees a la limite "Kimmeridgien-Portlandien" dans le Jura Neuchatelois meridional. Palaeont Zeitschr 53:163-181

De Loriol P (1886-1888) Etudes sur les mollusques des couches coralligènes de Valfin (Jura). Mém. Soc Pal Suisse, vol. 13-15

Deecke W (1916) Paläontologische Betrachtungen. 9. Über Gastropoden. Neues Jahrb Min Geol Pal 60:759-788

Dudley EC, Vermeij GJ (1978) Predation in time and space; drilling in the gastropod Turritella. Paleobiol 4:436-441

Föllmi KB, Bodin S, Godet A, Linder P, Van-De-Schootbrugge B (2007) Unlocking paleoenvironmental information from Early Cretaceous shelf sediments in the Helvetic Alps; stratigraphy is the key!. Swiss J Geosci 100:349-369

Frakes LA, Francis, JE, Syktus JI (eds) (1992) Climate modes of the Phanerozoic: the history of the earth's climate over the past 600 million years: Cambridge University Press, Cambridge

Frei E (1925) Zur Geologie des südöstlichen Neuenburger Juras. Beitr Geol Karte Schweiz NF 55 III Abt

Fürsich FT (1979) Genesis, environments, and ecology of Jurassic hardgrounds. N Jb Geol Paläont Abh 158:1-63

Gray JE (1840) Shells of molluscous animals. In: Synopsis of the contents of the British Museum, 42nd edn. London, pp 105-156

Gygi RA (2000a) Integrated stratigraphy of the Oxfordian and Kimmeridgian (Late Jurassic) in northern Switzerland and adjacent southern Germany. Memoire of the Swiss Academy of Sciences 104, Birkhäuser Verlag, Basel

Gygi RA (2000b) Annotated index of lithostratigraphic units currently used in the upper Jurassic of northern Switzerland. Eclogae Geol Helv 93:125-146

Hagadorn JW, Boyajian GE (1997) Subtle changes in mature predatorprey systems; an example from Neogene Turritella (Gastropoda). Palaios 12:372-379

Hallam A (1993) Jurassic climates as inferred from the sedimentary and fossil record. Philos Trans R Soc Lond [Biol] 341:287-296

Hallam A (2001) A review of the broad pattern of Jurassic sea-level changes and their possible causes in the light of current knowledge. Palaeogeogr Palaeoclimatol Palaeoecol 167:23-37

Hallock P, Schlager W (1986) Nutrient excess and the demise of coral reefs and carbonate platforms. Palaios 1:389-398

Hardenbol J, Thierry J, Farley MB, Jacquin T, de Graciansky PC, Vail PR (1998) Jurassic chronostratigraphy. In: de Graciansky PC, Hardenbol J, Jacquin T, Vail PR (eds) Mesozoic and Cenozoic sequence stratigraphy of European basins. SEPM Spec Publ 60 (chart)

Henning-Fischer S (2003) Geochemical and sedimentological evidence for environmental changes in the Valanginian (Early Cretaceous) of the Tethys region. PhD Thesis of the Swiss Federal Institute of Technology Zürich. Diss. ETH Nr. 15106

Herm D (1977) Zyklische Regressionssedimentation und Fossilvergesellschaftungen in der Gosau von Brandenberg (Tirol). Mitt Bayer Staatss Paläontol Hist Geol 17:257-277

Hillgärtner H (1998) Discontinuity surfaces on a shallow-marine carbonate platform (Berriasian, Valanginian, France and Switzerland). J Sediment Res 68:1093-1108

Jank M, Meyer CA, Wetzel A (2006a) Late Oxfordian to Late Kimmeridgian carbonate deposits of NW Switzerland (Swiss Jura): stratigraphical and palaeogeographical implications in the transition area between the Paris Basin and the Tethys. Sediment Geol 186:237-263

Jank M, Wetzel A, Meyer CA (2006b) A calibrated composite section for the Late Jurassic Reuchenette Formation in northwestern Switzerland (?Oxfordian, Kimmeridgian sensu gallico, Ajoie-Region). Eclogae Geol Helv 99:175-191

Jank M, Wetzel A, Meyer CA (2006c) Late Jurassic sea-level fluctuations in NW Switzerland (Late Oxfordian to Late Kimmeridgian):
Closing the gap between the Boreal and Tethyan realm in western Europe. Facies 52:487-519

Kidwell SM (1991) The stratigraphy of shell concentrations. In: Allison PA, Briggs DEG (eds) Taphonomy; releasing the data locked in the fossil record. Plenum Press, New York, pp 211-290

Kondo Y, Abbott ST, Kitamura A, Kamp PJJ, Naish TR, Kamataki T, Saul GS (1998) The relationship between shellbed type and sequence architecture; examples from Japan and New Zealand. In: Carter RM, Naish TR, Ito M, Pillans BJ (eds) Sequence stratigraphy in the Plio-Pleistocene; an evaluation. Elsevier, Amsterdam, pp 109-127

Linnæus C (1758) Systema naturæ per regna tria naturæ, secundum classes, ordines, genera, species, cum characteribus, differentiis, synonymis, locis. Tomus I. Editio decima, reformata. 824 p Holmiæ. (Salvius)

Lovén SL (1847) Malacozoologii. Öfversigt af Kongliga VetenskapsAkademiens Förhandlingar, Stokholm pp 175-199

Martin JH (1990) Glacial-interglacial $\mathrm{CO}_{2}$ change: the iron hypothesis Paleoceanography 5:1-13

Marty D (2008) Sedimentology, taphonomy, and ichnology of Late Jurassic dinosaur tracks from the Jura carbonate platform (Chevenez-Combe Ronde tracksite, NW Switzerland): insights into the tidal-flat palaeoenvironment and dinosaur diversity, locomotion, and palaeoecology. Dissertation, Geofocus 21, University of Fribourg

Marty D, Hug WA, Iberg A, Cavin L, Meyer CA, Lockley MG (2003) Preliminary report on the Courtedoux Dinosaur Tracksite from the Kimmeridgian of northern Switzerland. Ichnos 10:209-219

Matheron P (1842) Réunion extraordinaire de la Société Géologique à Aix. Bull Soc Géol France 13:411-532

Meert JG, Pruett FD, Merino E (2009) An "Inverse Conglomerate" paleomagnetic test and timing of in situ Terra Rossa Formation at Bloomington, Indiana. J Geol 117:126-138. doi:10.1086/596108

Meldahl KH (1993) Geographic gradients in the formation of shell concentrations; Plio-Pleistocene marine deposits, Gulf of California. Palaeogeogr Palaeoclimatol Palaeoecol 101:1-25

Merino E, Banerjee A (2008) Terra rossa genesis, implications for karst, and eolian dust: A geodynamic thread. J Geol 116:62-75. doi:10.1086/524675

Meyer CA (1990) Sauropod tracks from the Upper Jurassic Reuchenette formation (Kimmeridgian Lommiswil, Kt Solothurn) of northern Switzerland. Eclogae Geol Helv 83:389-397

Meyer CA (1993) A sauropod dinosaur megatracksite from the Late Jurassic of northern Switzerland. Ichnos 3:29-38

Meyer CA, Thüring B (2003) Dinosaurs of Switzerland. C R Palevol 2:103-117

Moore RC, Pitrat CW (1960) Treatise on invertebrate palaeontology, vol 1. Geological Society of America and University of Kansas Press, Lawrence

Moore GT, Hayashida DN, Ross CA, Jacobson SR (1992) Paleoclimate of the Kimmeridgian Tithonian (Late Jurassic) world. 1. Results using a general-circulation model. Palaeogeogr Palaeoclimatol Palaeoecol 93:113-150

Nara M (2002) Crowded Rosselia socialis in Pleistocene inner shelf deposits: Benthic paleoecology during rapid sea-level rise. Palaios 17:268-276

Parker WK, Jones TR, Bailey JW, Pourtales FL (1865) On some Foraminifera from the North Atlantic and Arctic Oceans, including Davis Straits and Baffin's Bay. Philos Trans R Soc Lond 155:325-441

Pchelintsev VF (1965) Mesozoic Murchisoniata from the strata of the Crimean Mountains. Science Publishing House Moscow, Moscow

Philippe M, Billon-Bruyat JP, Garcia-Ramos JC, Bocat L, Gomez B, Piñuela L (2010) New occurrences of the wood Protocupressinoxylon purbeckensis Francis: implications for terrestrial biomes 
in southwestern Europe at the Jurassic/Cretaceous boundary. Palaeontology 53:201-214

Pictet FJ, Campiche G (1862) Description des fossiles du terrain crétacé des environs de Sainte Croix. Deuxième Partie: Céphalopodes évolutes et Gastéropodes. Mat Pal Suisse, Librairie Georg, Genève

Ponder WF, Lindberg DR (1997) Towards a phylogeny of gastropod molluscs: an analysis using morphological characters. Zool J Linnean Soc 119:83-265

Pratt BR, James NP (1986) The St George Group (Lower Ordovician) of western Newfoundland: tidal flat island model for carbonate sedimentation in shallow epeiric seas. Sedimentology 33:313343

Rameil N (2005) Carbonate sedimentology, sequence stratigraphy and cyclostratigraphy of the Tithonian in the Swiss and French Jura Mountains. Dissertation, Geofocus 13, University of Fribourg

Reeve LA (1849) Conchologia iconica; or illustrations of the shells of molluscous animals. vol. 5, $147 \mathrm{pls}$

Raucsik B, Varga A (2008) Climato-environmental controls on clay mineralogy of the Hettangian-Bajocian successions of the Mecsek Mountains, Hungary: An evidence for extreme continental weathering during the early Toarcian oceanic anoxic event. Palaeogeogr Palaeoclimatol Palaeoecol 265:1-13

Rees PM, Ziegler AM, Valdes PJ (2000) Jurassic phytogeography and climates; new data and model comparisons. In: Huber BT, Macleod KG, Wing SL (eds) Warm climates in Earth history. Cambridge University Press, Cambridge, pp 297-318

Rees PM, Noto CR, Parrish JM, Parrish JT (2004) Late Jurassic climates, vegetation, and dinosaur distributions. J Geol 112:643653

Reolid M, Abad I, Martín-García JM (2008) Palaeoenvironmental implications of ferruginous deposits related to a Middle-Upper Jurassic discontinuity (Prebetic Zone, Betic Cordillera, southern Spain). Sediment Geol 203:1-16

Retallack GJ (1990) Soils of the past; an introduction to paleopedology. Unwin Hyman, Boston

Saucede T, Mooi R, David B (2007) Phylogeny and origin of Jurassic irregular echinoids (Echinodermata: Echinoidea). Geol Mag 144:333-359

Saul LR, Squires RL (2002) Added nerineoid gastropod evidence for a warm Turonian sea in southern California. J Paleontol 76:386390

Sharpe D (1850) Remarks on the genus Nerinea, with an account of the species found in Portugal. Quart J Geol Soc Lond 6:101-115

Signor PW (1982) Resolution of life habits using multiple morphologic criteria; shell form and life-mode in turritelliform gastropods. Paleobiol 8:378-388

Signor PW, Kat PW (1984) Functional significance of columellar folds in turritelliform gastropods. J Paleontol 58:210-216

Sirna G (1995) The Nerineids: taxonomy, stratigraphy and paleoecology with particular references to Italian examples. Geol Romana 31:285-306

Sohl NF (1987) Cretaceous gastropods: contrasts between Tethys and temperate provinces. J Paleontol 61:1085-1111

Squires RL, Saul LR (2007) Paleocene pareorine turritellid gastropods from the Pacific slope of North America. The Nautilus 121:1-16

Strasser A (1984) Black-pebble occurrence and genesis in Holocene carbonate sediments (Florida Keys, Bahamas, and Tunisia). J Sediment Petrol 54:1097-1109

Strasser A, Samankassou E (2003) Carbonate sedimentation rates today and in the past; Holocene of Florida Bay, Bahamas, and Bermuda vs. Upper Jurassic and Lower Cretaceous of the Jura Mountains (Switzerland and France). Geol Croatica 56:1-18

Tedesco LP, Wanless HR (1991) Generation of sedimentary fabrics and facies by repetitive excavation and storm infilling of burrow networks, Holocene of South Florida and Caicos Platform, B.W.I.
In: Bottjer DJ (ed) 13th International Sedimentological Congress, Ichnologic Symposium. SEPM, Tulsa, pp 326-343

Thalmann H (1966) Zur Stratigraphie des Oberen Malms im südlichen Berner- und Solothurner Jura. Mitt natf Ges Solothurn 22:4-125

Thierry J, Abbate E, Alekseev AS, Ait OR, Ait SH, Bouaziz S, Canerot J, Georgiev G, Guiraud R, Hirsch F, Ivanik M, Le MJ, Le NYM, Medina F, Mouty M, Nazarevich B, Nikishin AM, Page K, Panov DL, Pique A, Poisson A, Sandulescu M, Sapunov IG, Seghedi A, Soussi M, Tchoumatchenko PV, Vaslet D, Vishnevskaya V, Volozh YA, Voznezenski A, Walley CD, Wong TE, Ziegler M, Barrier E, Bergerat F, Bracene R, Brunet MF, Cadet JP, Guezou JC, Jabaloy A, Lepvrier C, Rimmele G, DeWever P, Baudin F, Belaid A, Bonneau M, Coutelle A, Fekirine B, Guillocheau F, Hantzpergue M, Julien M, Kokel F, Lamarche J, Mami L, Mansy JL, Mascle G, Pascal C, Robin C, Stephenson R, Sihamdi N, Vera JA, Vuks VJ (2000a) Early Kimmeridgian (146-144 Ma). In: Dercourt J, Gaetani M, Vrielynck B, Barrier E, Biju-Duval B, Brunet MF, Cadet JP, Crasquin S, Sandulescu M (eds) Peri-Tethys atlas; palaeogeographical maps; explanatory notes. Commission for the Geologic Map of the World, Paris, pp 85-97

Thierry J, Abbate E, Alekseev AS, Ait OR, Ait SH, Bouaziz S, Canerot J, Georgiev G, Guiraud R, Hirsch F, Ivanik M, Le MJ, Le NYM, Medina F, Mouty M, Nazarevich B, Nikishin AM, Page K, Panov DL, Pique A, Poisson A, Sandulescu M, Sapunov IG, Seghedi A, Soussi M, Tchoumatchenko PV, Vaslet D, Vishnevskaya V, Volozh YA, Voznezenski A, Walley CD, Wong TE, Ziegler M, Barrier E, Bergerat F, Bracene R, Brunet MF, Cadet JP, Guezou JC, Jabaloy A, Lepvrier C, Rimmele G, DeWever P, Baudin F, Belaid A, Bonneau M, Coutelle A, Fekirine B, Guillocheau F, Hantzpergue M, Julien M, Kokel F, Lamarche J, Mami L, Mansy JL, Mascle G, Pascal C, Robin C, Stephenson R, Sihamdi N, Vera JA, Vuks VJ (2000b) Early Tithonian (141-139 Ma). In: Dercourt J, Gaetani M, Vrielynck B, Barrier E, Biju-Duval B, Brunet MF, Cadet JP, Crasquin S, Sandulescu M (eds) Peri-Tethys atlas; palaeogeographical maps; explanatory notes. Commission for the Geologic Map of the World, Paris, pp 98-110

Tichy G (1980) Gastropoden als Leitfossilien? Geol Paläontol Mitt Insbruck 9:239-261

Tudhope AW, Scoffin TP (1994) Growth and structure of fringing reefs in a muddy environment, South Thailand. J Sediment Res 64:752-767

Vogel K (1968) Zur Lebensweise des Gastropoden Nerinea. Neues Jahrb Geol Palaeontol Monatshefte 3:181-184

Waite R, Wetzel A, Meyer CA, Strasser A (2008) The paleoecological significance of nerineoid mass accumulations from the Kimmeridgian of the Swiss Jura Mountains. Palaios 23:548-558. doi:10.2110/palo.2007.p07-048r

Waite R, Marty D, Strasser A (2009) Masked evidence for terra rossa type soil formation on the Kimmeridgian platform of the Swiss Jura. Seventeenth Meeting of Swiss Sedimentologists-Fribourg, February 21, p 51

Wanless HR, Tedesco LP, Tyrrell KM (1988) Production of subtidal tubular and surficial tempestites by Hurricane Kate, Caicos Platform, British West Indies. J Sediment Res 58:739-750

Wenz W (1938-1944) Gastropoda, Teil 1, Allgemeiner Teil und Prosobranchia. In: Schindewolf $\mathrm{OH}$ (ed), Handbuch der Paläozoologie, Bornträger Berlin

Wieczorek J (1979) Upper Jurassic nerineacean gastropods from the Holy Cross Mountains (Poland). Acta Palaeont Polonica 24:299-350

Wieczorek J (1992) Biogeography of the Jurassic and the Cretaceous nerineacean gastropods: abstracts of the 29th International Geological Congress, Kyoto, Japan, p. 106

Wildi W, Funk H, Loup B, Amato E, Huggenberger P (1989) Mesozoic subsidence history of the European marginal shelves of the alpine Tethys (Helvetic realm, Swiss Plateau and Jura). Eclogae Geol Helv 82:817-840 
Wright VP (1994) Paleosols in shallow marine carbonate sequences. Earth Sci Rev 35:367-395

Zeuschner L (1849) Geognostische Beschreibung des Nerineen-Kalkes von Inwald und Roczyny. Naturwiss Abh 3:1-14

Ziegler B (1964) Boreale Einflüsse im Oberjura Westeuropas. Geologische Rundschau 54:250-261

Ziegler B (1983). Einführung in die Palaeobiologie, Teil II, Spezielle Paläontologie, Protisten, Spongien und Coelenteraten, Mollusken. E. Schweizerbart'sche Verlagsbuchhandlung Stuttgart
Ziegler B (1992) Einführung in die Palaeobiologie, Teil I, Allgemeine Paläontologie. E. Schweizerbart'sche Verlagsbuchhandlung, Stuttgart

Zittel KA (1873) Die Gastropoden der Stramberger Schichten. Palaeontographica: Beiträge zur Naturgeschichte der Vorwelt, Supplement Band 2, 3:193-373 